Prepared in cooperation with the

New York State Department of Environmental Conservation

\title{
Groundwater Quality in the Mohawk River Basin, New York, 2011
}

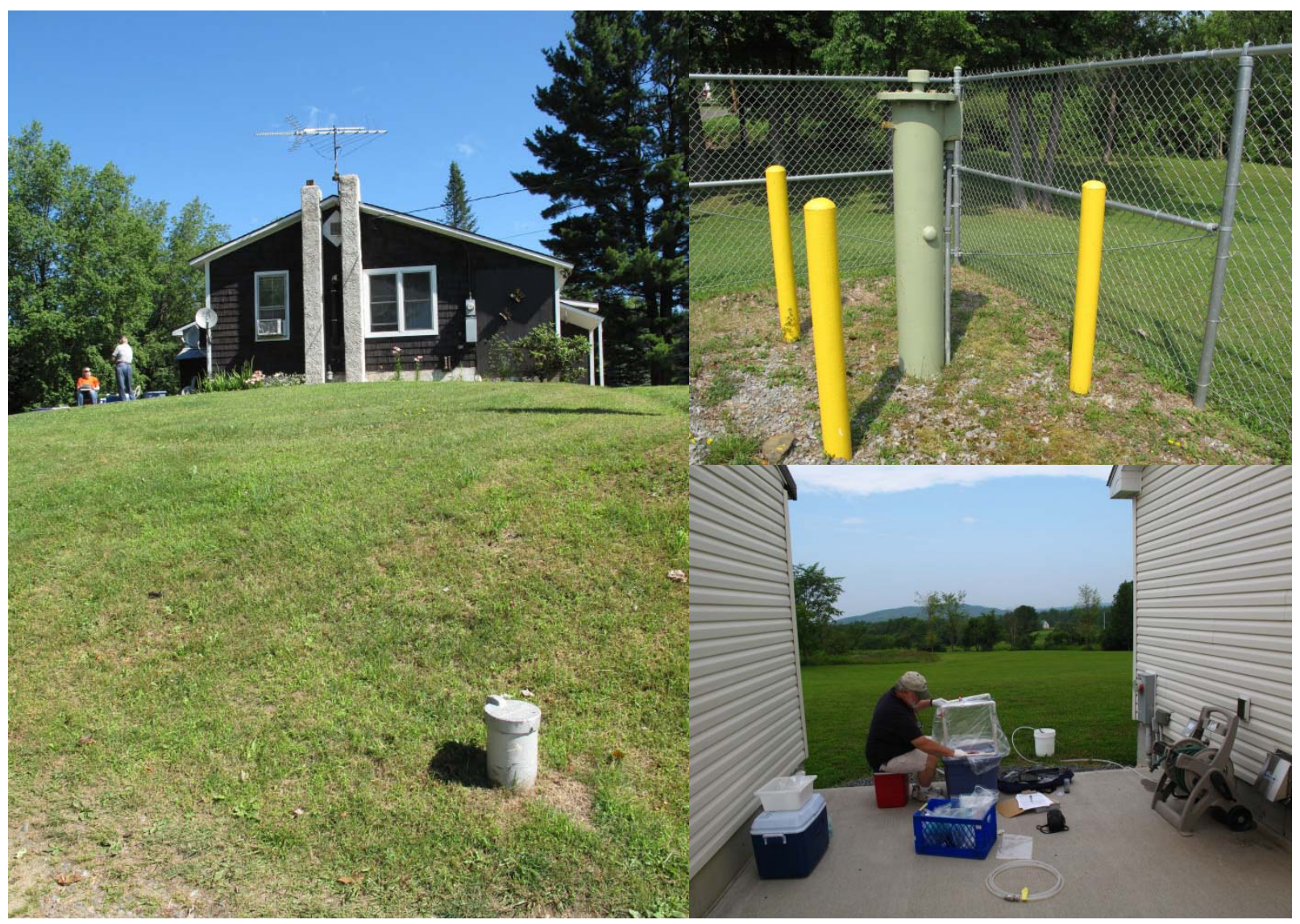

Open-File Report 2013-1021 
Cover. (Clockwise from left) A domestic well in Herkimer County, New York (photograph by Carolyn VanAlstyne); a production well in Schoharie County, New York (photograph by Paul M. Heisig); a U.S. Geological Survey scientist sampling a well in Herkimer County, New York (photograph by Paul M. Heisig). 


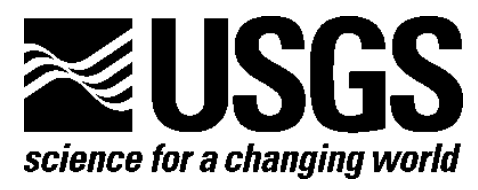

Prepared in cooperation with the New York State Department of Environmental Conservation

\section{Groundwater Quality in the Mohawk River Basin, New York, 2011}

By Elizabeth A. Nystrom and Tia-Marie Scott

Open-File Report 2013-1021

U.S. Department of the Interior

U.S. Geological Survey 


\section{U.S. Department of the Interior \\ KEN SALAZAR, Secretary}

\section{U.S. Geological Survey \\ Marcia K. McNutt, Director}

U.S. Geological Survey, Reston, Virginia: 2013

For more information on the USGS-the Federal source for science about the Earth, its natural and living resources, natural hazards, and the environment-visit http://www.usgs.gov or call 1-888-ASK-USGS

For an overview of USGS information products, including maps, imagery, and publications, visit $h$ ttp://www.usgs.gov/pubprod

To order this and other USGS information products, visit http://store.usgs.gov

Suggested citation:

Nystrom, E.A., and Scott, T., 2013, Groundwater quality in the Mohawk River Basin, New York, 2011: U.S. Geological Survey Open-File Report 2013-1021, 43 p., at http://pubs.usgs.gov/of/2013/1021/.

Any use of trade, product, or firm names is for descriptive purposes only and does not imply endorsement by the U.S. Government.

Although this report is in the public domain, permission must be secured from the individual copyright owners to reproduce any copyrighted material contained within this report. 


\section{Contents}

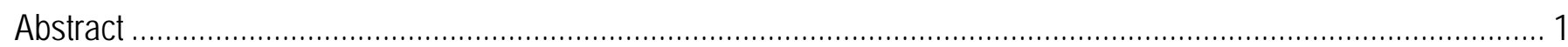

Introduction

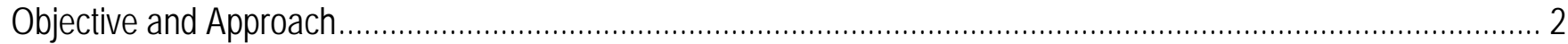

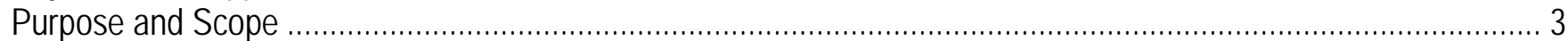

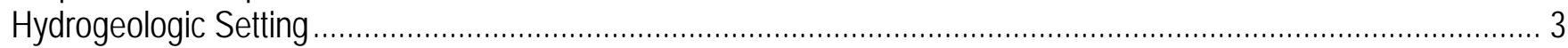

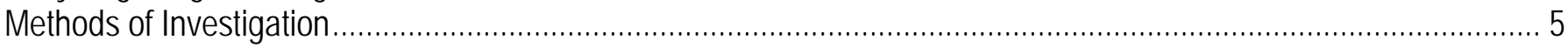

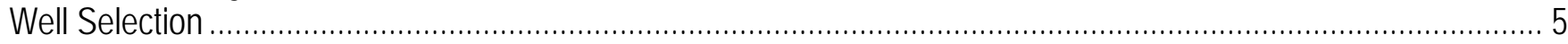

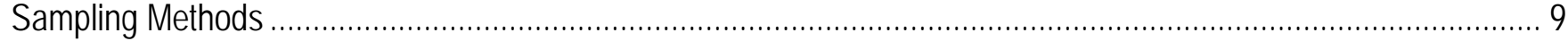

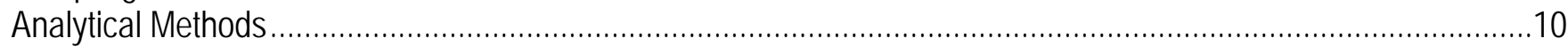

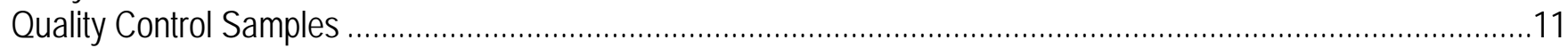

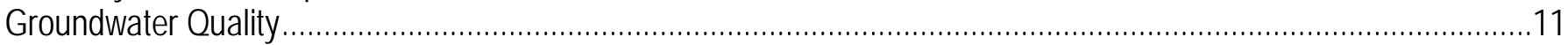

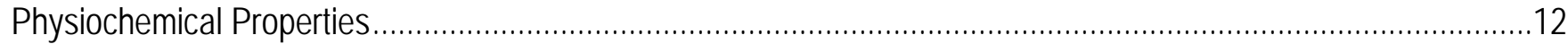

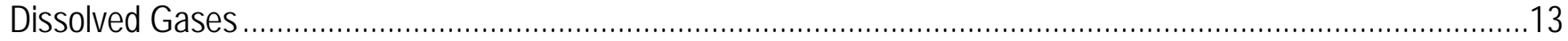

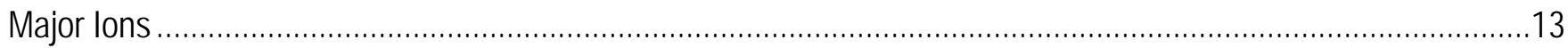

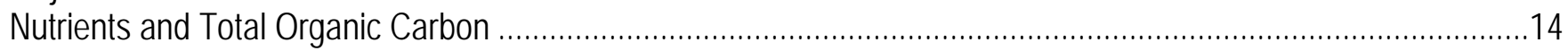

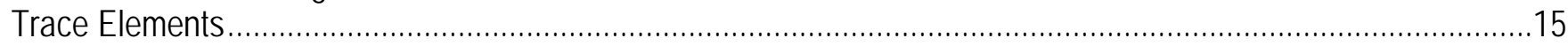

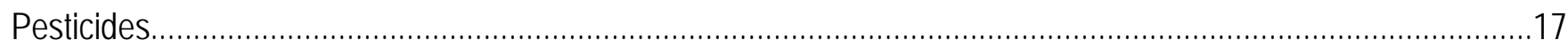

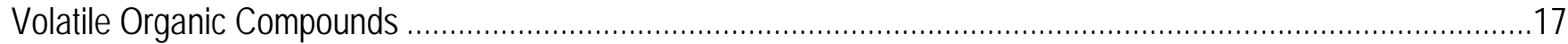

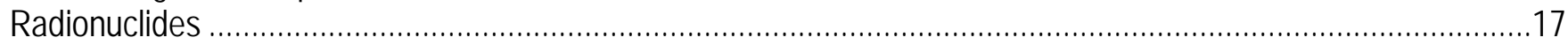

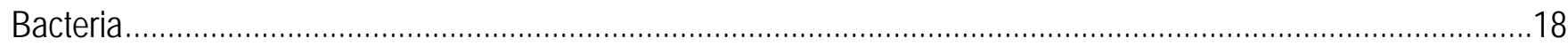

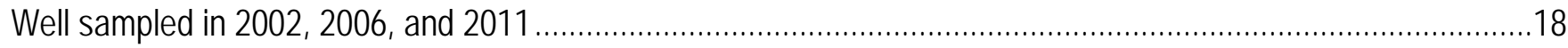

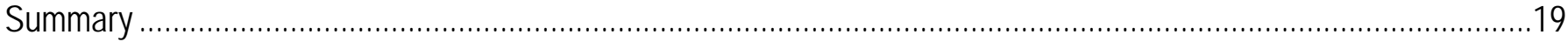

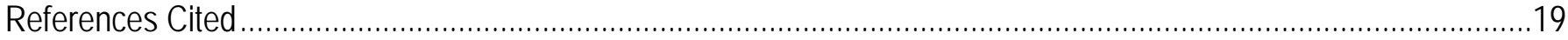

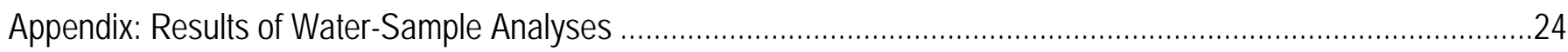

\section{Figures}

Maps showing:

Figure 1. Topography and geography of the Mohawk River Basin, New York.

Figure 2. Generalized bedrock geology of the Mohawk River Basin, New York, and locations of wells sampled in 2011.

Figure 3. Generalized surficial geology of the Mohawk River Basin, New York, and locations of wells sampled in 2011.

\section{Tables}

Table 1. Previous groundwater-quality studies and reports.

Table 2. Information on wells from which water samples were collected in the Mohawk River Basin, New York, 2011.

Table 3. Summary of information on wells from which water samples were collected in the Mohawk River Basin, New York, 2011

Table 4. Drinking-water standards and summary statistics for physiochemical properties of groundwater samples from the Mohawk River Basin, New York, 2011.

Table 5. Summary statistics for concentrations of dissolved gases in groundwater samples from the Mohawk River Basin, New York, 2011. 
Table 6. Drinking-water standards and summary statistics for concentrations of major ions in groundwater samples from the Mohawk River Basin, New York, 2011.

Table 7. Drinking-water standards and summary statistics for concentrations of nutrients in groundwater samples from the Mohawk River Basin, New York, 2011.

Table 8. Drinking-water standards and summary statistics for concentrations of trace elements in groundwater samples from the Mohawk River Basin, New York, 2011.

Table 9. Drinking-water standards and summary statistics for concentrations of radionuclides in groundwater samples from the Mohawk River Basin, New York, 2011.

\section{Appendix 1}

Table 1-1. Constituents that were not detected in groundwater samples collected from 21 wells in the Mohawk River Basin, New York, 2011.......

Table 1-2. Physiochemical properties of groundwater samples collected in the Mohawk River Basin, New York, 2011.

Table 1-3. Concentrations of dissolved gases in groundwater samples collected in the Mohawk River Basin, New York, 2011.

Table 1-4. Concentrations of major ions in groundwater samples collected in the Mohawk River Basin, New York, 2011.

Table 1-5. Concentrations of nutrients and organic carbon in groundwater samples collected in the Mohawk River Basin, New York, 2011.

Table 1-6. Concentrations of trace elements in groundwater samples collected in the Mohawk River Basin, New York, 2011.

Table 1-7. Concentrations of pesticides detected in groundwater samples collected in the Mohawk River Basin, New York, 2011.

Table 1-8. Concentrations of volatile organic compounds detected in groundwater samples collected in the Mohawk River Basin, New York, 2011.

Table 1-9. Activities of radionuclides in groundwater samples from the Mohawk River Basin, New York, 2011... 36

Table 1-10. Bacteria in groundwater samples collected in the Mohawk River Basin, New York, 2011.

Table 1-11. Physiochemical properties and concentrations of nutrients in groundwater samples collected in the Mohawk River Basin, New York, 2002, 2006, and 2011.

Table 1-12. Concentrations of major ions in groundwater samples collected in the Mohawk River Basin, New York, 2002, 2006, and 2011.

Table 1-13. Concentrations of trace elements and radionuclides in groundwater samples in the Mohawk River Basin, New York, 2002, 2006, and 2011.

Table 1-14. Concentrations of pesticides and of volatile organic compounds detected in groundwater samples collected in the Mohawk River Basin, New York, 2002, 2006, and 2011.

Table 1-15. Bacteria in groundwater samples collected in the Mohawk River Basin, New York, 2006 and 2011... 43 
Conversion Factors

\begin{tabular}{|c|c|c|}
\hline Multiply & By & To obtain \\
\hline \multicolumn{3}{|c|}{ Length } \\
\hline inch (in.) & 2.54 & centimeter $(\mathrm{cm})$ \\
\hline foot $(\mathrm{ft})$ & 0.3048 & meter (m) \\
\hline mile (mi) & 1.609 & kilometer $(\mathrm{km})$ \\
\hline \multicolumn{3}{|c|}{ Area } \\
\hline square mile $\left(\mathrm{mi}^{2}\right)$ & 259.0 & hectare (ha) \\
\hline square mile $\left(\mathrm{mi}^{2}\right)$ & 2.590 & square kilometer $\left(\mathrm{km}^{2}\right)$ \\
\hline \multicolumn{3}{|c|}{ Volume } \\
\hline gallon (gal) & 3.785 & liter $(\mathrm{L})$ \\
\hline \multicolumn{3}{|c|}{ Flow rate } \\
\hline gallon per minute (gal/min) & 0.06309 & liter per second $(\mathrm{L} / \mathrm{s})$ \\
\hline \multicolumn{3}{|c|}{ Pressure } \\
\hline inch of mercury at $60^{\circ} \mathrm{F}$ (in $\mathrm{Hg}$ ) & 3.377 & kilopascal $(\mathrm{kPa})$ \\
\hline \multicolumn{3}{|c|}{ Radioactivity } \\
\hline picocurie per liter (pCi/L) & 0.037 & becquerel per liter $(\mathrm{Bq} / \mathrm{L})$ \\
\hline
\end{tabular}

Temperature in degrees Celsius $\left({ }^{\circ} \mathrm{C}\right)$ may be converted to degrees Fahrenheit $\left({ }^{\circ} \mathrm{F}\right)$ as follows:

${ }^{\circ} \mathrm{F}=\left(1.8 \mathrm{x}^{\circ} \mathrm{C}\right)+32$

Temperature in degrees Fahrenheit $\left({ }^{\circ} \mathrm{F}\right)$ may be converted to degrees Celsius $\left({ }^{\circ} \mathrm{C}\right)$ as follows:

${ }^{\circ} \mathrm{C}=\left({ }^{\circ} \mathrm{F}-32\right) / 1.8$

Vertical coordinate information is referenced to the North American Vertical Datum of 1988 (NAVD 88).

Horizontal coordinate information is referenced to the North American Datum of 1983 (NAD 83).

Elevation, as used in this report, refers to distance above the vertical datum.

Specific conductance is given in microsiemens per centimeter at 25 degrees Celsius $\left(\mu \mathrm{S} / \mathrm{cm}\right.$ at $\left.25^{\circ} \mathrm{C}\right)$.

Concentrations of chemical constituents in water are given either in milligrams per liter (mg/L) or micrograms per liter $(\mu \mathrm{g} / \mathrm{L})$. 


\section{List of Abbreviations and Acronyms}

$\begin{array}{ll}\text { AMCL } & \text { Alternative maximum contaminant level } \\ \text { CFCL } & \text { USGS Chlorofluorocarbon Laboratory } \\ \text { CFU } & \text { Colony-forming units } \\ \text { cICP-MS } & \text { Collision/reaction cell inductively coupled plasma-mass spectrometry } \\ \text { CIAT } & \text { 2-Chloro-4-isopropylamino-6-amino-s-triazine } \\ \text { GC-MS } & \text { Gas chromatography-mass spectrometry } \\ \text { GPS } & \text { Global positioning system } \\ \text { HPLC-MS } & \text { High-performance liquid chromatography-mass spectrometry } \\ \text { ICP-AES } & \text { Inductively coupled plasma-atomic emission spectrometry } \\ \text { ICP-MS } & \text { Inductively coupled plasma-mass spectrometry } \\ \text { ICP-OES } & \text { Inductively coupled plasma-optical emission spectrometry } \\ \text { LRL } & \text { Laboratory reporting level } \\ \text { MCL } & \text { Maximum contaminant level } \\ \text { MTBE } & \text { Methyl tert-butyl ether } \\ \text { NAVD 88 } & \text { North American Vertical Datum of 1988 } \\ \text { NWIS } & \text { National Water Information System } \\ \text { NWQL } & \text { USGS National Water Quality Laboratory } \\ \text { NYSDEC } & \text { New York State Department of Environmental Conservation } \\ \text { NYSDOH } & \text { New York State Department of Health } \\ \text { PERC } & \text { Tetrachloroethene } \\ \text { PVC } & \text { Polyvinyl chloride } \\ \text { SDWS } & \text { Secondary drinking-water standards } \\ \text { THM } & \text { Trihalomethane } \\ \text { USEPA } & \text { U.S. Environmental Protection Agency } \\ \text { USGS } & \text { U.S. Geological Survey } \\ \text { VOC } & \text { Volatile organic compound }\end{array}$




\title{
Groundwater Quality in the Mohawk River Basin, New York, 2011
}

\author{
By Elizabeth A. Nystrom and Tia-Marie Scott
}

\begin{abstract}
Water samples were collected from 21 production and domestic wells in the Mohawk River Basin in New York in July 2011 to characterize groundwater quality in the basin. The samples were collected and processed using standard U.S. Geological Survey procedures and were analyzed for 148 physiochemical properties and constituents, including dissolved gases, major ions, nutrients, trace elements, pesticides, volatile organic compounds (VOCs), radionuclides, and indicator bacteria.

The Mohawk River Basin covers 3,500 square miles in New York and is underlain by shale, sandstone, carbonate, and crystalline bedrock. The bedrock is overlain by till in much of the basin, but surficial deposits of saturated sand and gravel are present in some areas. Nine of the wells sampled in the Mohawk River Basin are completed in sand and gravel deposits, and 12 are completed in bedrock. Groundwater in the Mohawk River Basin was typically neutral or slightly basic; the water typically was very hard. Bicarbonate, chloride, calcium, and sodium were the major ions with the greatest median concentrations; the dominant nutrient was nitrate. Methane was detected in 15 samples. Strontium, iron, barium, boron, and manganese were the trace elements with the highest median concentrations. Four pesticides, all herbicides or their degradates, were detected in four samples at trace levels; three VOCs, including chloroform and two solvents, were detected in four samples. The greatest radon-222 activity, 2,300 picocuries per liter, was measured in a sample from a bedrock well, but the median radon activity was higher in samples from sand and gravel wells than in samples from bedrock wells. Coliform bacteria were detected in five samples with a maximum of 92 colony-forming units per 100 milliliters.

Water quality in the Mohawk River Basin is generally good, but concentrations of some constituents equaled or exceeded current or proposed Federal or New York State drinking-water standards. The standards exceeded are color (1 sample), $\mathrm{pH}$ (1 sample), sodium (9 samples), chloride (1 sample), sulfate (2 samples), dissolved solids (7 samples), aluminum (3 samples), iron (8 samples), manganese (6 samples), radon-222 (10 samples), and bacteria (5 samples). Fecal coliform bacteria and Escherichia coli (E. coli) were each detected in one sample. Concentrations of fluoride, nitrate, nitrite, antimony, arsenic, barium, beryllium, cadmium, chromium, copper, lead, mercury, selenium, silver, thallium, zinc, and uranium, and gross alpha activities, did not exceed existing drinking-water standards in any of the samples collected. Methane concentrations in two samples were greater than 28 milligrams per liter, and the maximum measured concentration was 44.3 milligrams per liter.
\end{abstract}

\section{Introduction}

Groundwater is used as a source of drinking water by approximately one-quarter of the population of New York State (Kenny and others, 2009). In 2002, the U.S. Geological Survey (USGS), in cooperation with the New York State Department of Environmental Conservation (NYSDEC), developed a program to evaluate groundwater quality throughout the major river basins in New York on a rotating basis. The program parallels the NYSDEC Rotating Intensive Basin Study program 
(http://www.dec.ny.gov/chemical/30951.html), which evaluates surface-water quality on a 5-year cycle by sampling in 2 or 3 of the 14 major river basins in the State each year, and supports NYSDEC's responsibilities under Section 305(b) of the Clean Water Act Amendments of 1977 to report on the chemical quality of groundwater within New York (U.S. Environmental Protection Agency, 1997).

The groundwater-quality program began in 2002 with a pilot study in the Mohawk River Basin and has continued throughout upstate New York since then (table 1). Sampling completed in 2008 represents the conclusion of a first round of groundwater-quality sampling throughout New York State (excluding Long Island, which is monitored through local county programs). Groundwater-quality sampling was conducted in 2011 in the Mohawk River Basin, Niagara and Allegheny River Basins, and Lake Erie and western Lake Ontario tributaries.

Table 1. Previous groundwater-quality studies and reports.

\begin{tabular}{|c|c|c|c|}
\hline Study area & Year & Report & Reference \\
\hline Mohawk River Basin & 2002 & Water-Data Report NY-02-1 & Butch and others, 2003 \\
\hline Chemung River Basin & 2003 & Open-File Report 2004-1329 & Hetcher-Aguila, 2005 \\
\hline Lake Champlain Basin & 2004 & Open-File Report 2006-1088 & Nystrom, 2006 \\
\hline Susquehanna River Basin & 2004 & Open-File Report 2006-1161 & $\begin{array}{l}\text { Hetcher-Aguila and Eckhardt, } \\
2006\end{array}$ \\
\hline Delaware River Basin & 2005 & Open-File Report 2007-1098 & Nystrom, 2007b \\
\hline Genesee River Basin & 2005 & Open-File Report 2007-1093 & Eckhardt and others, 2007 \\
\hline St. Lawrence River Basin & 2005 & Open-File Report 2007-1066 & Nystrom, 2007a \\
\hline Mohawk River Basin & 2006 & Open-File Report 2008-1086 & Nystrom, 2008 \\
\hline Western New York & 2006 & Open-File Report 2008-1140 & Eckhardt and others, 2008 \\
\hline Central New York & 2007 & Open-File Report 2009-1257 & Eckhardt and others, 2009 \\
\hline Upper Hudson River Basin & 2007 & Open-File Report 2009-1240 & Nystrom, 2009 \\
\hline Chemung River Basin & 2008 & Open-File Report 2011-1112 & Risen and Reddy, 2011a \\
\hline Eastern Lake Ontario Basin & 2008 & Open-File Report 2011-1074 & Risen and Reddy, 2011b \\
\hline Lower Hudson River Basin & 2008 & Open-File Report 2010- 1197 & Nystrom, 2010 \\
\hline Lake Champlain Basin & 2009 & Open-File Report 2011- 1180 & Nystrom, 2011 \\
\hline Susquehanna River Basin & 2009 & Open-File Report 2012- 1045 & Reddy and Risen, 2012 \\
\hline Delaware River Basin & 2010 & Open-File Report 2011- 1320 & Nystrom, 2012 \\
\hline Genesee River Basin & 2010 & Open-File Report 2012- 1135 & Reddy, 2012 \\
\hline St. Lawrence River Basin & 2010 & Open-File Report 2011- 1320 & Nystrom, 2012 \\
\hline
\end{tabular}

\section{Objective and Approach}

The objective of the groundwater-quality monitoring program is to quantify and report on ambient groundwater quality from bedrock and glacial-drift aquifers in upstate New York. Using consistent, standardized methods, groundwater-quality samples were collected from existing domestic and production wells using on-site, permanently installed pumps, then analyzed. Wells were selected to represent an approximately equal number of domestic and production wells, to represent an approximately equal number of bedrock and glacial-drift wells, and to provide a representative geographic distribution of samples with emphasis on areas of greatest groundwater use. As basins were sampled for the second or third time, approximately 20 percent of samples were collected from wells that previously have been sampled as part of the cycle of studies. 
Samples were analyzed for a broad suite of constituents, including physiochemical properties and concentrations of dissolved gases, major ions, nutrients, trace elements, pesticides, volatile organic compounds (VOCs), radionuclides, and indicator bacteria. The resulting data set will be used to establish a groundwater-quality baseline for New York State, characterizing naturally occurring and background conditions, and to identify long-term trends. The data are made available through the USGS National Water Information System (NWIS) (http://nwis.waterdata.usgs.gov/ny/nwis/qw) and project reports.

Groundwater-quality samples were collected in the Mohawk River Basin (excluding the Schoharie subbasin) in 2002 and in the complete Mohawk River Basin in 2006 and 2011. In 2011, 21 environmental samples and 3 quality-assurance samples were collected during the month of July. Four of the wells sampled in 2011 were also sampled as part of this cycle of studies in 2002 and 2006 (Butch and others, 2003; and Nystrom, 2008).

\section{Purpose and Scope}

This report presents the findings of the 2011 study in the Mohawk River Basin, in which 21 groundwater-quality samples were collected during July 2011. The report (1) describes the hydrogeologic setting, sampled wells, and the methods of site selection, sample collection, and chemical analysis; (2) presents discussions of the analytical results; and (3) presents comparisons of the results of this study with results for selected wells in the Mohawk River Basin that were sampled in 2002 and 2006 (Butch and others, 2003; and Nystrom, 2008).

\section{Hydrogeologic Setting}

The Mohawk River Basin encompasses approximately 3,500 square miles $\left(\mathrm{mi}^{2}\right)$ in central New York (fig. 1) and all or parts of 14 counties, including all of Montgomery County, most of Schoharie and Schenectady Counties, part of Herkimer, Hamilton, Fulton, Greene, Oneida, Saratoga, and Albany Counties, and small parts of Lewis, Madison, Otsego, and Delaware Counties (fig. 1). The Mohawk River is a major tributary to the Hudson River; the major tributaries to the Mohawk River are the Schoharie and West Canada Creeks (fig. 1). The Mohawk River Basin contains three major reservoirs (fig. 1): the Schoharie Reservoir, which diverts water out of the basin as part of New York City's watersupply system; Hinckley Reservoir, which provides drinking water to the Utica area, and Delta Reservoir.

The highest elevations in the Mohawk River Basin are approximately 4,000 ft above the North American Vertical Datum of 1988 (NAVD 88) along the southern edge of the basin. The Mohawk River Valley runs from west to east along the middle of the basin; the lowest elevation (approximately $10 \mathrm{ft}$ ) in the basin is at the confluence of the Mohawk River and the Hudson River north of Troy, N.Y. (fig. 1). The Mohawk River Basin is predominantly forested, especially in upland areas, with urban and agricultural areas mainly in valleys and other low-lying areas (Vogelmann and others, 2001); urban centers and adjacent developed areas in the Mohawk River Basin include Schenectady, Utica, and Amsterdam (fig. 1).

The surficial material (fig. 2) throughout the basin was deposited primarily during the last glaciations of the Pleistocene epoch when the Wisconsin glaciers covered most of the Northeast (Reynolds, 1990). Till mantles the uplands and ice-contact, deltaic, fluvial-, and alluvial sand and gravel and lacustrine silt and clay are present in the valleys. Till and lacustrine silt and clay deposits generally have low yields of water, whereas the well-sorted, coarse-grained deposits form important aquifers in the basin. The valley-fill sand-and-gravel aquifers may produce yields of as much as 500 gallons per minute (gal/min) (Reynolds, 1990). 


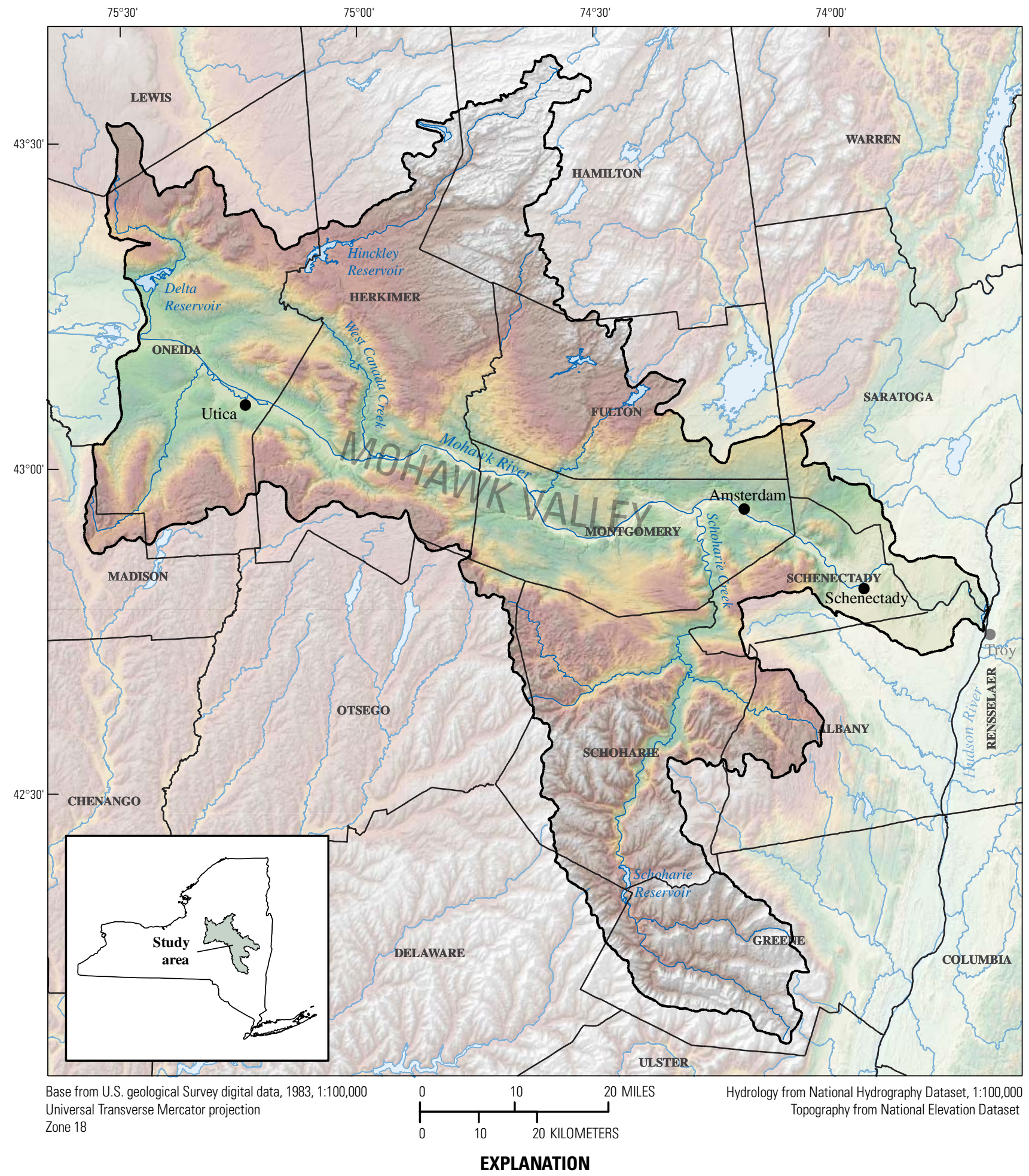

Elevation,

in feet above the

North American

Vertical Datum of 1988

5,333 feet

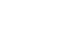

$\square$ Study area

Water

10 feet

Figure 1. Map showing topography and geography of the Mohawk River Basin, New York. 
Bedrock in the Mohawk River Basin (fig. 3) includes shale, sandstone, carbonate, and crystalline rocks. Black shale is present in the Mohawk Valley, with bands of carbonate rock along the edges of the valley. Bedrock in the southern part of the basin consists mainly of shale and sandstone, and bedrock in the northern part of the basin is mainly crystalline metamorphic rock. Of the bedrock aquifers in the basin, carbonate rocks generally produce the highest yields, and the crystalline rocks generally produce the lowest; the clastic rocks generally have low to moderate yields (Hammond and others, 1978).

\section{Methods of Investigation}

The methods used in this study, including (1) well-selection criteria, (2) sampling methods, and (3) analytical methods, were designed to maximize data precision, accuracy, and comparability. Groundwater-sample collection and processing followed standard USGS procedures as documented in the National Field Manual for the Collection of Water-Quality Data (U.S. Geological Survey, variously dated). Samples were analyzed by documented methods at the USGS National Water Quality Laboratory (NWQL) in Denver, Colorado, and other laboratories.

\section{Well Selection}

The 21 wells selected for sampling (figs. 2 and 3) represent forested, developed, and agricultural areas (table 2). The final selection of each well was based on the availability of well-construction data and hydrogeologic information for the well and its surrounding area. The study did not target specific municipalities, industries, or agricultural practices.

The domestic wells were selected on the basis of information from the NYSDEC Water Well program, which began in 2000. The program requires that licensed well drillers file a report with NYSDEC containing basic information about each well drilled, such as well and casing depth, diameter, yield, and a hydrogeologic log. Inspection of well-completion report data identified several hundred wells as potential sampling sites; well owners were each sent a letter requesting permission to sample the well and a questionnaire about the well. Well owners who granted permission were contacted later by phone to verify well information and to arrange a convenient time for sampling.

Production wells considered for sampling were identified through the U.S. Environmental Protection Agency (USEPA) Safe Drinking Water Information System, the New York State Department of Health (NYSDOH) Drinking Water Protection Program, and the NYSDEC Water Well program. Town officials and (or) water managers were sent letters requesting permission to sample a well, and follow-up phone calls were made to arrange a time for sampling. Well information, such as depth, was provided by water managers if a well-completion report was unavailable. The aquifer type indicated for sampled wells was assigned through inspection of hydrogeologic logs and published geologic maps, including Fisher and others (1970) and Cadwell (1991).

The characteristics of the wells sampled and the type of land cover surrounding each well are listed in table 2. The depths of the wells, the aquifer units from which samples were collected, and the numbers of production and domestic wells are summarized in table 3. Four wells sampled in 2011 (HE 622, OE1460, SA1501, and MT 406) were also sampled in 2002 and 2006 (Butch and others, 2003; Nystrom, 2008). 


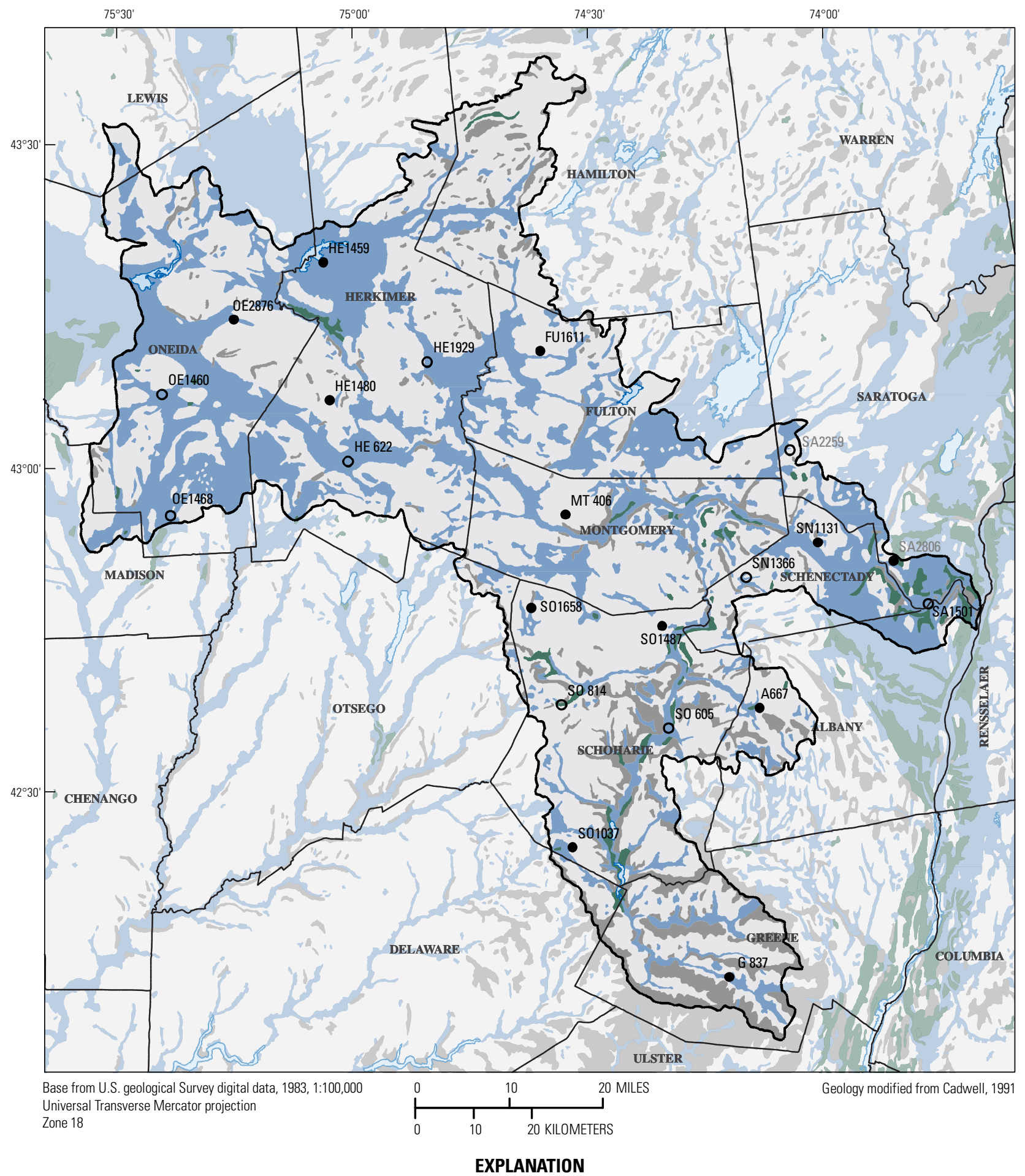

Surficial material

$\begin{array}{ll}\text { Sand and gravel } & \text { Till } \\ \text { Silt and clay } & \square \text { Water } \\ \text { Rock } & \end{array}$

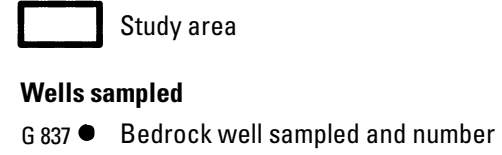

S0 814 S Sand and gravel well sampled and number

Figure 2. Map showing generalized bedrock geology of the Mohawk River Basin, New York, and locations of wells sampled in 2011. 


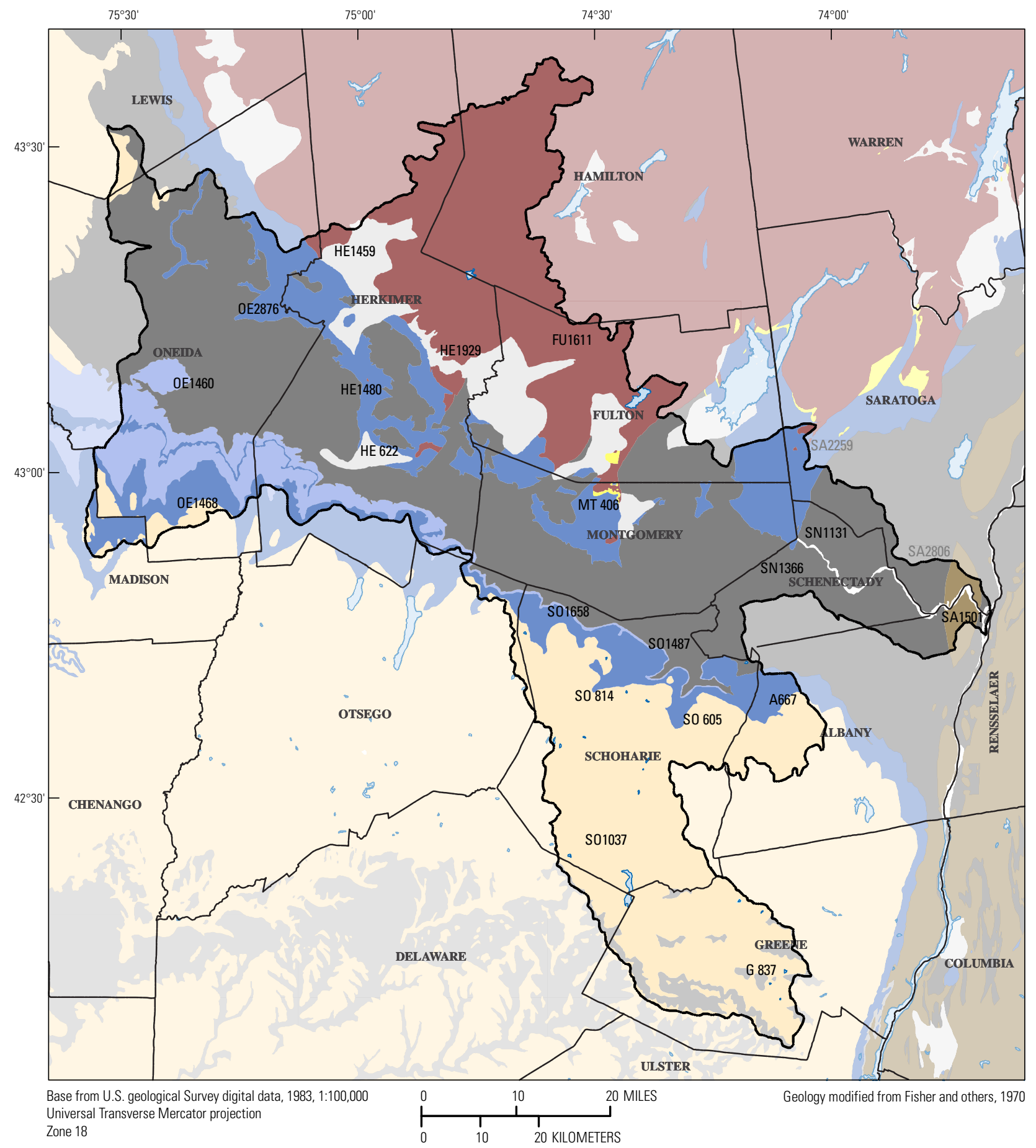

EXPLANATION

Generalized bedrock geology

\begin{tabular}{|l}
\hline Carbonates \\
Shale and carbonates \\
Shale \\
Black Shale \\
Shale and sandstone
\end{tabular}

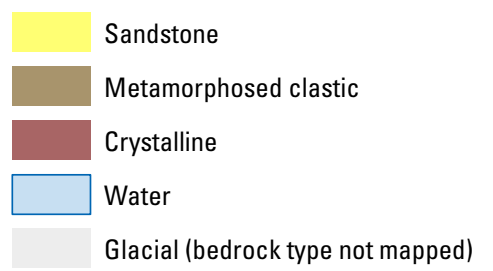

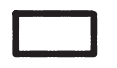

Study area

Wells sampled

G 837 Bedrock well sampled and number

So 814 Sand and gravel well sampled and number

Figure 3. Map showing generalized surficial geology of the Mohawk River Basin, New York, and locations of wells sampled in 2011. 
Table 2. Description of wells from which water samples were collected in the Mohawk River Basin, New York, 2011.

[--, unknown; well types: P, production; D, domestic. Land cover categories: D, $\square$ developed; F, $\square$ forested;

A, $\square$ agricultural; W, $\square$ open water; WL, $\square$ wetlands. Well locations are shown in figures 2 and 3]

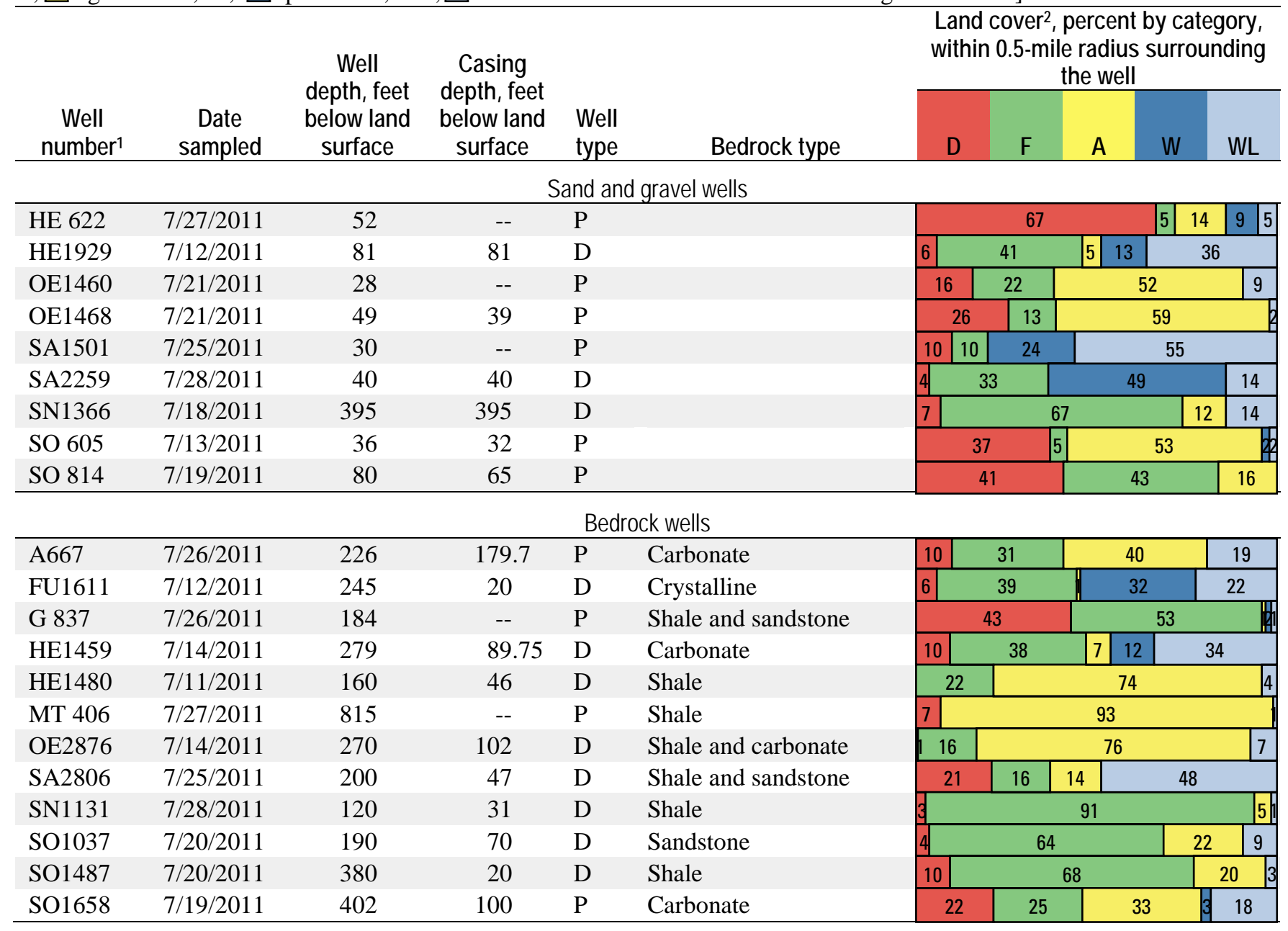

${ }^{1}$ A, Albany County; FU, Fulton County; G, Greene County; HE, Herkimer County; MT, Montgomery County; OE, Oneida County; SA, Saratoga County; SN, Schenectady County; SO, Schoharie County.

${ }^{2}$ Determined from the National Land Cover Data set (Vogelmann and others, 2001). 
Table 3. Summary of information on wells from which water samples were collected in the Mohawk River Basin, New York, 2011.

[bls, below land surface]

\begin{tabular}{|c|c|c|c|}
\hline \multirow[b]{2}{*}{ Type of well } & \multicolumn{3}{|c|}{ Number of wells } \\
\hline & Production & Domestic & Total \\
\hline Wells completed in sand and gravel (depth 28 to 395 feet bls) & 6 & 3 & 9 \\
\hline Wells completed in bedrock (depth 120 to 815 feet bls) & 4 & 8 & 12 \\
\hline Carbonate bedrock & 2 & 1 & 3 \\
\hline Shale and carbonate bedrock & 0 & 1 & 1 \\
\hline Shale bedrock & 1 & 3 & 4 \\
\hline Shale and sandstone bedrock & 1 & 1 & 2 \\
\hline Sandstone bedrock & 0 & 1 & 1 \\
\hline Crystalline bedrock & 0 & 1 & 1 \\
\hline Total number of wells & 10 & 11 & 21 \\
\hline
\end{tabular}

\section{Sampling Methods}

Samples were collected and processed in accordance with documented USGS protocols (U.S. Geological Survey, variously dated). The samples were collected before any water-treatment system to be as representative of the aquifer water quality as possible. Most samples from domestic wells were collected from a spigot near the pressure tank; samples from production wells were collected at the spigot or faucet used for collection of raw-water samples by water managers.

At sites with garden-hose type spigots, samples were collected from one or more 10-ft lengths of Teflon tubing attached to the spigot. Domestic wells were purged after the tubing was connected by running to waste for at least 20 minutes at pumping rates ranging from about 2 to $5 \mathrm{gal} / \mathrm{min}$ or until at least one well-casing volume of water had passed the sampling point. Wells that had been used recently required removal of less than three well-casing volumes (U.S. Geological Survey, 2006). At least three well-casings of water were pumped from production wells before sampling; several were pumped for 1 hour or more prior to sampling, typically at rates of about 100 gal/min. During well purging, notes about the well and surrounding land and land use were recorded, including a global positioning system (GPS) measurement of latitude and longitude. After the well was purged, field measurements of water temperature, $\mathrm{pH}$, specific conductance, and dissolved oxygen concentration were recorded at regular intervals until these values had stabilized, after which the sample was collected (U.S. Geological Survey, variously dated).

The flow rate for sample collection was adjusted to less than $0.5 \mathrm{gal} / \mathrm{min}$ when possible. The Teflon sampling tube was then connected to a sample-collection chamber constructed of a polyvinyl chloride (PVC) frame and a clear plastic chamber bag. The Teflon tubing and spigot-attachment equipment for each sample were pre-cleaned in the laboratory with a dilute phosphate-free detergent solution, followed by rinses with tap water and deionized water. Equipment for filtration of pesticide samples was rinsed with methanol as described in Wilde (2004).

Samples were collected and preserved in the sampling chamber according to standard USGS procedures. Samples for nutrient, major-ion, and some trace-element analyses were filtered through disposable (one-time use) 0.45-micrometer $(\mu \mathrm{m})$ pore-size polyether sulfone capsule filters that were preconditioned in the laboratory with 3 liters (L) of deionized water the day of sample collection. Samples for pesticide analyses were filtered through baked $0.7-\mu \mathrm{m}$ pore-size glass fiber filters. Ultra- 
pure nitric acid preservation was required for trace-element samples, except mercury, which was preserved with hydrochloric acid. Hydrochloric acid was added to VOC samples to kill bacteria that might degrade VOCs; samples for major-cation analysis and some samples for radiochemical analysis were preserved with ultra-pure nitric acid. Acid preservative was added after the collection of other samples to avoid the possibility of cross contamination by the acid preservative; for example, samples preserved with nitric acid were acidified after the collection of samples for nutrient analysis. Samples for bacterial analysis were collected in accordance with NYSDEC and NYSDOH protocols, except that the tap from which each water sample was collected was not flame sterilized. Water samples for radon analysis were collected through a septum chamber with a glass syringe, according to standard USGS procedures. Water samples for the analysis of dissolved gases were filled and sealed while submerged in a beaker of water to prevent exposure to the atmosphere. Water samples analyzed by NYSDOHcertified laboratories were collected in bottles provided by the analyzing laboratory. After collection, all water samples except those for radiochemical analyses were chilled to 4 degrees Celsius $\left({ }^{\circ} \mathrm{C}\right)$ or less and were kept chilled until delivery to the analyzing laboratory. Bacterial samples were hand delivered to the analyzing laboratory within 6 hours of collection; all other samples were shipped by overnight delivery to the designated laboratories.

Most sampling sites had easy access to a garden-hose type spigot; however, some supply wells did not. Wells A667, HE622, OE1460, OE1468, SO605, SO814 were sampled from faucets using adapters to connect the Teflon tubing. Well SA1501 was sampled from a hydrant, and well SO1658 was sampled from a 4-inch discharge pipe at which water-system personnel routinely collect raw-water samples. The syringe for radon-222 sample collection at these sites was inserted directly into the flowing water in the throat of the tap to minimize sample exposure to the atmosphere.

\section{Analytical Methods}

Samples were analyzed for 148 physiochemical properties and constituents, including dissolved gases, major ions, nutrients, trace elements, pesticides, pesticide degradates, VOCs, radionuclides, and bacteria. Physiochemical properties such as water temperature, $\mathrm{pH}$, dissolved oxygen concentration, and specific conductance were measured at the sampling site. Major ions, nutrients, total organic carbon, trace elements, radon-222, pesticides, pesticide degradates, and VOCs were analyzed at the USGS NWQL in Denver, Colo. Selected dissolved gases were analyzed at the USGS Chlorofluorocarbon Laboratory (CFCL) in Reston, Virginia. Gross alpha and gross beta radioactivities were analyzed at Eberline Services in Richmond, California. Indicator bacteria were analyzed at the NYSDOH-certified St. Peter's Bender Laboratory in Albany, N.Y.

Anion concentrations were measured by ion-exchange chromatography, and cation concentrations were measured by inductively coupled plasma-atomic emission spectrometry (ICP-AES), as described in Fishman (1993). Nutrients were analyzed by colorimetry, as described by Fishman (1993), and Kjeldahl digestion with photometric finish, as described by Patton and Truitt (2000). Total organic carbon samples were analyzed by high temperature combustion and catalytic oxidation for measurement by infrared detection according to Standard Method 5310 (American Public Health Association, 1998). Mercury concentrations were measured through cold vapor-atomic fluorescence spectrometry according to methods described by Garbarino and Damrau (2001). Arsenic, chromium, and nickel samples were analyzed by use of collision/reaction cell inductively coupled plasma-mass spectrometry (cICP-MS), as described by Garbarino and others (2006). The remaining trace elements were analyzed by ICP-AES (Struzeski and others, 1996), inductively coupled plasma-optical emission spectrometry (ICP-OES), and inductively coupled plasma-mass spectrometry (ICP-MS) (Garbarino and Struzeski, 1998). Procedures for in-bottle digestions for trace-element analyses described by Hoffman 
and others (1996) were followed. Radon-222 activities were measured through liquid-scintillation counting (ASTM International, 2006). Samples for pesticide analyses were processed as described by Wilde and others (2004) and were analyzed using gas chromatography-mass spectrometry (GC-MS) and high-performance liquid chromatography-mass spectrometry (HPLC-MS), as described by Zaugg and others (1995), Sandstrom and others (2001), and Furlong and others (2001). VOCs were analyzed by GC-MS using methods described by Connor and others (1998).

Gross alpha and gross beta radioactivities were measured through gas flow proportional counting according to USEPA method 900.0 (U.S. Environmental Protection Agency, 1980). Carbon dioxide and methane concentrations were measured through gas chromatography with flame ionization detection; dissolved nitrogen gas and argon concentrations were measured through gas chromatography with thermal conductivity detection. Indicator bacteria samples were tested for total coliform, fecal coliform, and Escherichia coli (E. coli) using membrane filtration through Standard Method 9222 (American Public Health Association, 1998); a heterotrophic plate count test (SM 9215 B) also was done.

\section{Quality-Control Samples}

In addition to the 21 groundwater samples, 1 field blank sample, 1 replicate sample, and 1 pesticide spike sample were collected for quality assurance. Constituents did not exceed laboratory reporting levels (LRLs) in the blank sample, except for total organic carbon, which was measured at 0.5 milligrams per liter $(\mathrm{mg} / \mathrm{L})$. The variability between replicate samples was greatest for unfiltered trace elements, gross alpha radioactivity, and radon-222. No VOCs or pesticides were detected in the replicate samples. The median recovery in the pesticide spike sample, which was collected at site A667, was 79 percent; constituents with 60 to 70 percent recovery include benfluralin, diazinon, dieldrin, fipronil sulfone, malathion, metribuzin, propyzamide, and tebuthiuron. Constituents with less than 50 percent recovery include fonofos (47 percent recovery), phorate (44 percent), terbufos (40 percent), disulfoton (30 percent), 2-chloro-4-isopropylamino-6-amino-s-triazine (CIAT, 25 percent), p,p'-DDE (23 percent), propargite (20 percent), and cis-permethrin (1 percent); of these compounds, disulfoton, CIAT, and propargite are known to have highly variable recovery rates in the analysis method used and are routinely coded as estimated values.

\section{Groundwater Quality}

Many of the constituents for which the groundwater samples were analyzed were not detected in any sample. Some concentrations are reported as "estimated.” Estimated concentrations are typically reported when the detected value is less than the established LRL or when recovery of a compound has been shown to be highly variable (Childress and others, 1999). Concentrations of some constituents exceeded maximum contaminant levels (MCLs) or secondary drinking-water standards (SDWS) set by the USEPA (U.S. Environmental Protection Agency, 2009) or NYSDOH (New York State Department of Health, 2011). MCLs are enforceable standards for finished water in public water supplies; they are not enforceable for private homeowner wells but are presented here as a standard for evaluation of the water-quality results. SDWS are nonenforceable drinking-water standards that typically relate to aesthetic concerns such as taste, odor, or staining of plumbing fixtures.

The results of analyses of the 21 groundwater samples collected in the Mohawk River Basin during July 2011 are presented in tables 1-1 through 1-10 in appendix 1. Of the 148 constituents and physiochemical properties analyzed for, 82 were not detected at levels greater than the LRLs (appendix table 1-1). Results for the remaining 66 constituents and properties that were detected in the Mohawk River Basin are presented in appendix 1, tables 1-2 through 1-10. 


\section{Physiochemical Properties}

Most (16) of the samples from the Mohawk River Basin had a color of less than $(<) 1$ platinumcobalt (Pt-Co) unit (table 4 and appendix table 1-2); one sample from a bedrock well had a color of 175 Pt-Co units, exceeding the NYSDOH MCL and USEPA SDWS of 15 Pt-Co units. Sample pH was typically near neutral or slightly basic (median 7.5 for all wells) and ranged from 6.5 to 8.9 . The $\mathrm{pH}$ of one sample from a bedrock well was higher than the USEPA SDWS range for $\mathrm{pH}$ (6.5 to 8.5). Specific conductance ranged from 194 to 1,470 microsiemens per centimeter at 25 degrees Celsius $(\mu \mathrm{S} / \mathrm{cm}$ at $25^{\circ} \mathrm{C}$ ); the median conductance was $542 \mu \mathrm{S} / \mathrm{cm}$ at $25^{\circ} \mathrm{C}$. Water temperature ranged from 9.4 to $16.0^{\circ} \mathrm{C}$; the median temperature was $11.5^{\circ} \mathrm{C}$. Hydrogen sulfide odor was detected at seven sites, most (six) of which were bedrock wells.

Table 4. Drinking-water standards and summary statistics for physiochemical properties of groundwater samples from the Mohawk River Basin, New York, 2011.

[All concentrations in unfiltered water except as noted; Pt-Co units, platinum-cobalt units; $\mu \mathrm{S} / \mathrm{cm}$ at $25^{\circ} \mathrm{C}$, microsiemens per centimeter at 25 degrees Celsius; ${ }^{\circ} \mathrm{C}$, degrees Celsius; --, not applicable; <, less than]

\begin{tabular}{|c|c|c|c|c|c|c|c|c|c|}
\hline \multirow[b]{3}{*}{ Constituent } & \multicolumn{9}{|c|}{ Summary statistics for physical properties } \\
\hline & \multirow{2}{*}{$\begin{array}{l}\text { Drinking- } \\
\text { water } \\
\text { standard }\end{array}$} & \multirow{2}{*}{$\begin{array}{l}\text { Number of } \\
\text { samples } \\
\text { exceeding } \\
\text { standard }\end{array}$} & \multirow{2}{*}{$\begin{array}{c}\text { Median } \\
\text { (all samples) }\end{array}$} & \multicolumn{3}{|c|}{$\begin{array}{c}\text { Sand and gravel aquifers } \\
\text { (9 samples) }\end{array}$} & \multicolumn{3}{|c|}{$\begin{array}{c}\text { Bedrock aquifers } \\
\text { (12 samples) }\end{array}$} \\
\hline & & & & Minimum & Median & Maximum & Minimum & Median & Maximum \\
\hline Color, filtered, Pt-Co units & ${ }^{1} 15$ & 1 & $<1$ & $<1$ & $<1$ & 5 & $<1$ & $<1$ & 175 \\
\hline $\mathrm{pH}$ & ${ }^{1} 6.5-8.5$ & 1 & 7.5 & 6.8 & 7.3 & 8.0 & 6.5 & 7.6 & 8.9 \\
\hline $\begin{array}{l}\text { Specific conductance, } \\
\mu \mathrm{S} / \mathrm{cm} \text { at } 25^{\circ} \mathrm{C}\end{array}$ & -- & -- & 542 & 194 & 835 & 1,470 & 286 & 534 & 1,450 \\
\hline Temperature, ${ }^{\circ} \mathrm{C}$ & -- & -- & 11.5 & 9.6 & 11.5 & 15.2 & 9.4 & 11.6 & 16.0 \\
\hline
\end{tabular}

${ }^{1}$ U.S. Environmental Protection Agency Secondary Drinking Water Standard. 


\section{Dissolved Gases}

Dissolved oxygen concentrations ranged from $<0.3$ to $6.8 \mathrm{mg} / \mathrm{L}$ (table 5 and appendix table 1-3) and typically were greater in samples from sand and gravel wells (median $3.9 \mathrm{mg} / \mathrm{L}$ ) than in samples from bedrock wells (median $<0.3 \mathrm{mg} / \mathrm{L}$ ). The concentrations of carbon dioxide, argon, dissolved nitrogen gas, and methane were determined twice for each site (table 1-3). The median concentrations of these dissolved gases in the samples were $22.09 \mathrm{mg} / \mathrm{L}$ for nitrogen, $17.0 \mathrm{mg} / \mathrm{L}$ for carbon dioxide, $0.7546 \mathrm{mg} / \mathrm{L}$ for argon, and $0.013 \mathrm{mg} / \mathrm{L}$ for methane. Methane was detected in 15 of the 21 samples; concentrations were generally greater in samples from bedrock wells (median $0.573 \mathrm{mg} / \mathrm{L}$ ) than in samples from sand and gravel wells (median $0.0014 \mathrm{mg} / \mathrm{L}$ ). The maximum methane concentration measured was $44.3 \mathrm{mg} / \mathrm{L}$ in a sample from a well finished in black shale and limestone. Although the USEPA and NYSDOH do not have MCLs for methane, dissolved methane concentrations greater than $28 \mathrm{mg} / \mathrm{L}$ (2 samples) can pose explosion hazards as a result of methane accumulation in confined spaces; in addition, the Office of Surface Mining recommends that methane concentrations ranging from 10 to $28 \mathrm{mg} / \mathrm{L}$ in water (1 sample) signify an action level where the situation should be closely monitored, and if the concentration increases, the area should be vented to prevent methane gas buildup (Eltschlager and others, 2001).

Table 5. Summary statistics for concentrations of dissolved gases in groundwater samples from Mohawk River Basin, New York, 2011.

[All concentrations in unfiltered water; mg/L, milligrams per liter; <, less than]

\begin{tabular}{|c|c|c|c|c|c|c|c|}
\hline \multirow[b]{3}{*}{ Constituent } & \multicolumn{7}{|c|}{ Summary statistics for concentrations of dissolved gases } \\
\hline & \multirow{2}{*}{$\begin{array}{c}\text { Median } \\
\text { (all samples) }\end{array}$} & \multicolumn{3}{|c|}{$\begin{array}{c}\text { Sand and gravel aquifers } \\
\text { (9 samples) }\end{array}$} & \multicolumn{3}{|c|}{$\begin{array}{c}\text { Bedrock aquifers } \\
\text { (12 samples) }\end{array}$} \\
\hline & & Minimum & Median & Maximum & Minimum & Median & Maximum \\
\hline Carbon dioxide, mg/L & 17.0 & 1.7 & 20.2 & 37.8 & 0.3 & 14.7 & 47.1 \\
\hline Dissolved oxygen, mg/L & $<0.3$ & $<0.3$ & 3.9 & 6.8 & $<0.3$ & $<0.3$ & 2.2 \\
\hline Argon, mg/L & 0.7546 & 0.6101 & 0.7331 & 1.171 & 0.6387 & 0.8067 & 0.9661 \\
\hline Nitrogen gas, mg/L & 22.09 & 16.66 & 19.85 & 39.85 & 16.16 & 23.29 & 33.62 \\
\hline Methane, mg/L & 0.013 & $<0.001$ & .0014 & 0.143 & $<0.001$ & 0.573 & 44.3 \\
\hline
\end{tabular}

\section{Major Ions}

The anions detected in the highest concentrations were bicarbonate (median concentration 258 $\mathrm{mg} / \mathrm{L}$ ) and chloride (median concentration $64.9 \mathrm{mg} / \mathrm{L}$ ) (table 6 and appendix table 1-4). The cations detected in the highest concentrations were calcium (median concentration $63.6 \mathrm{mg} / \mathrm{L}$ ) and sodium (median concentration $56.6 \mathrm{mg} / \mathrm{L}$ ). The concentration of sodium in nine samples exceeded the USEPA Drinking Water Advisory Taste Threshold of $60 \mathrm{mg} / \mathrm{L}$; the maximum concentration of sodium detected was $273 \mathrm{mg} / \mathrm{L}$. The concentration of chloride in one sample, $393 \mathrm{mg} / \mathrm{L}$, exceeded the NYSDOH MCL and USEPA SDWS of $250 \mathrm{mg} / \mathrm{L}$. The concentration of sulfate in two samples exceeded the NYSDOH MCL and USEPA SDWS of $250 \mathrm{mg} / \mathrm{L}$; the maximum concentration of sulfate detected in the samples was $453 \mathrm{mg} / \mathrm{L}$. The concentration of fluoride did not exceed established MCLs in any sample (table 6).

Most of the water samples (13 of 21) from the Mohawk River Basin were very hard (greater than $180 \mathrm{mg} / \mathrm{L}$ as calcium carbonate, $\mathrm{CaCO}_{3}$; Hem, 1985). The median hardness of the samples was 204 $\mathrm{mg} / \mathrm{L}$ as $\mathrm{CaCO}_{3}$, and the maximum hardness was $636 \mathrm{mg} / \mathrm{L}$ as $\mathrm{CaCO}_{3}$. Of the remaining eight samples, two were soft ( 0 to $60 \mathrm{mg} / \mathrm{L}$ as $\mathrm{CaCO}_{3}$ ), five were moderately hard (61 to $120 \mathrm{mg} / \mathrm{L}$ as $\mathrm{CaCO}_{3}$ ), and one 
was hard (121 to $180 \mathrm{mg} / \mathrm{L}$ as $\mathrm{CaCO}_{3}$ ). Alkalinity ranged from 48 to $289 \mathrm{mg} / \mathrm{L}$ as $\mathrm{CaCO}_{3}$; the median was $212 \mathrm{mg} / \mathrm{L}$ of $\mathrm{CaCO}_{3}$. Dissolved solids concentrations ranged from 125 to 1,090 mg/L with a median of $436 \mathrm{mg} / \mathrm{L}$; dissolved solids concentration in seven samples exceeded, and one sample equaled, the USEPA SDWS for total dissolved solids of $500 \mathrm{mg} / \mathrm{L}$.

Table 6. Drinking-water standards and summary statistics for concentrations of major ions in groundwater samples from the Mohawk River Basin, New York, 2011.

[All concentrations are in milligrams per liter in filtered water; --, not applicable; <, less than; ${ }^{\circ} \mathrm{C}$, degrees Celsius; $\mathrm{CaCO}_{3}$, calcium carbonate]

\begin{tabular}{|c|c|c|c|c|c|c|c|c|c|c|}
\hline & \multirow[b]{3}{*}{ Constituent } & \multicolumn{9}{|c|}{ Summary statistics for concentrations of major ions } \\
\hline & & \multirow{2}{*}{$\begin{array}{l}\text { Drinking- } \\
\text { water } \\
\text { standard }\end{array}$} & \multirow{2}{*}{$\begin{array}{l}\text { Number of } \\
\text { samples } \\
\text { exceeding } \\
\text { standard }\end{array}$} & \multirow{2}{*}{$\begin{array}{l}\text { Median } \\
\text { (all } \\
\text { samples) }\end{array}$} & \multicolumn{3}{|c|}{$\begin{array}{c}\text { Sand and gravel aquifers } \\
\text { (9 samples) }\end{array}$} & \multicolumn{3}{|c|}{$\begin{array}{c}\text { Bedrock aquifers } \\
\text { (12 samples) }\end{array}$} \\
\hline & & & & & Minimum & Median & Maximum & Minimum & Median & Maximum \\
\hline \multirow{4}{*}{ : } & Calcium & -- & -- & 63.6 & 24.2 & 87.6 & 120 & 7.14 & 38.9 & 214 \\
\hline & Magnesium & -- & -- & 16.6 & 2.91 & 21.1 & 53.8 & 0.781 & 14.3 & 37.7 \\
\hline & Potassium & -- & -- & 1.91 & 0.47 & 1.46 & 3.40 & 0.29 & 2.04 & 6.68 \\
\hline & Sodium & ${ }^{4} 60$ & 9 & 56.6 & 2.51 & 40.0 & 150 & 11.7 & 64.3 & 273 \\
\hline \multirow{5}{*}{$\frac{\text { 은 }}{\frac{0}{c}}$} & Bicarbonate & -- & -- & 258 & 59 & 258 & 352 & 95 & 238 & 310 \\
\hline & Chloride & ${ }^{2,3} 250$ & 1 & 64.9 & 3.01 & 24.6 & 188 & 7.63 & 77.0 & 393 \\
\hline & Fluoride & $\begin{array}{l}{ }^{1} 4.0 \\
{ }^{2} 2.2 \\
{ }^{3} 2\end{array}$ & 0 & 0.36 & $<0.04$ & 0.06 & 0.55 & 0.20 & 0.42 & 1.55 \\
\hline & Silica & -- & -- & 8.94 & 5.10 & 7.57 & 13.5 & 7.38 & 9.22 & 17.5 \\
\hline & Sulfate & ${ }^{2,3} 250$ & 2 & 18.1 & 5.01 & 31.9 & 453 & 1.31 & 16.0 & 388 \\
\hline \multicolumn{2}{|c|}{ Hardness as $\mathrm{CaCO}_{3}$} & -- & -- & 204 & 72.5 & 301 & 520 & 21.0 & 176 & 636 \\
\hline \multicolumn{2}{|c|}{ Alkalinity as $\mathrm{CaCO}_{3}$} & -- & -- & 212 & 48 & 212 & 289 & 78 & 195 & 255 \\
\hline \multicolumn{2}{|c|}{$\begin{array}{l}\text { Dissolved solids, dried } \\
\text { at } 180^{\circ} \mathrm{C}\end{array}$} & ${ }^{3} 500$ & 7 & 436 & 125 & 473 & 1,090 & 170 & 378 & 1,040 \\
\hline
\end{tabular}

${ }^{1}$ U.S. Environmental Protection Agency Maximum Contaminant Level.

${ }^{2}$ New York State Department of Health Maximum Contaminant Level.

${ }^{3}$ U.S. Environmental Protection Agency Secondary Drinking Water Standard.

${ }^{4}$ U.S. Environmental Protection Agency Drinking Water Advisory Taste Threshold.

\section{Nutrients and Total Organic Carbon}

The dominant nutrient detected in the Mohawk River Basin was nitrate (table 7 and appendix table 1-5). The concentration of ammonia ranged from $<0.010$ to $2.07 \mathrm{mg} / \mathrm{L}$ as nitrogen (N) and was generally greater in samples from the 12 bedrock wells (median $0.448 \mathrm{mg} / \mathrm{L}$ as $\mathrm{N}$ ) than in samples from the 9 sand and gravel wells (median $<0.010 \mathrm{mg} / \mathrm{L}$ as $\mathrm{N}$ ). The concentration of nitrate ranged from $<0.013$ to $3.48 \mathrm{mg} / \mathrm{L}$ as $\mathrm{N}$ and was generally greater in samples from sand and gravel wells (median $0.456 \mathrm{mg} / \mathrm{L}$ as $\mathrm{N}$ ) than in samples from bedrock wells (median $<0.020 \mathrm{mg} / \mathrm{L}$ as $\mathrm{N}$ ). The concentration of nitrate plus nitrite did not exceed the NYSDOH and USEPA MCL of $10 \mathrm{mg} / \mathrm{L}$ as $\mathrm{N}$ in any sample. Nitrite was detected in 7 of the 21 samples with a maximum concentration of $0.020 \mathrm{mg} / \mathrm{L}$ as $\mathrm{N}$; the concentration of nitrite did not exceed the NYSDOH and USEPA MCL ( $1 \mathrm{mg} / \mathrm{L}$ as $\mathrm{N}$ ) in any sample. Orthophosphate concentrations ranged from 0.005 to $0.155 \mathrm{mg} / \mathrm{L}$ as phosphorus (P). Total organic carbon was detected in 18 of the 21 samples; the maximum concentration was $11.3 \mathrm{mg} / \mathrm{L}$. 
Table 7. Drinking-water standards and summary statistics for concentrations of nutrients in groundwater samples from the Mohawk River Basin, New York, 2011.

[All concentrations in milligrams per liter in filtered water except as noted. N, nitrogen; P, phosphorus; --, not applicable; <, less than]

\begin{tabular}{|c|c|c|c|c|c|c|c|c|c|}
\hline \multirow[b]{3}{*}{ Constituent } & \multicolumn{9}{|c|}{ Summary statistics for concentrations of nutrients } \\
\hline & \multirow{2}{*}{$\begin{array}{l}\text { Drinking- } \\
\text { water } \\
\text { standard }\end{array}$} & \multirow{2}{*}{$\begin{array}{l}\text { Number of } \\
\text { samples } \\
\text { exceeding } \\
\text { standard }\end{array}$} & \multirow{2}{*}{$\begin{array}{c}\text { Median } \\
\text { (all } \\
\text { samples) }\end{array}$} & \multicolumn{3}{|c|}{$\begin{array}{c}\text { Sand and gravel aquifers } \\
\text { (9 samples) }\end{array}$} & \multicolumn{3}{|c|}{$\begin{array}{c}\text { Bedrock aquifers } \\
\text { (12 samples) }\end{array}$} \\
\hline & & & & Minimum & Median & Maximum & Minimum & Median & Maximum \\
\hline Ammonia plus organic $\mathrm{N}$, as $\mathrm{N}$ & -- & -- & 0.23 & $<0.05$ & 0.07 & 0.84 & $<0.05$ & 0.57 & 2.4 \\
\hline Ammonia $\left(\mathrm{NH}_{3}\right)$, as $\mathrm{N}$ & -- & -- & 0.100 & $<0.010$ & $\begin{array}{c}<0.01 \\
0\end{array}$ & 0.715 & $<0.010$ & 0.448 & 2.07 \\
\hline $\begin{array}{l}\text { Nitrate plus nitrite }\left(\mathrm{NO}_{2}+\right. \\
\left.\mathrm{NO}_{3}\right) \text {, as } \mathrm{N}\end{array}$ & 1,210 & 0 & 0.04 & $<0.02$ & 0.46 & 3.48 & $<0.02$ & $<0.02$ & 0.55 \\
\hline Nitrate $\left(\mathrm{NO}_{3}\right)$, as $\mathrm{N}$ & ${ }^{1,2} 10$ & 0 & 0.038 & $<0.016$ & 0.456 & 3.48 & $<0.013$ & $<0.020$ & 0.550 \\
\hline Nitrite $\left(\mathrm{NO}_{2}\right)$, as $\mathrm{N}$ & 1,21 & 0 & $<0.001$ & $<0.001$ & $\begin{array}{l}<0.00 \\
1\end{array}$ & 0.004 & $<0.001$ & $<0.001$ & 0.020 \\
\hline Orthophosphate $\left(\mathrm{PO}_{4}\right)$, as $\mathrm{P}$ & -- & -- & 0.011 & 0.005 & 0.007 & 0.022 & 0.007 & 0.011 & 0.155 \\
\hline Total organic carbon, unfiltered & -- & -- & 0.7 & $<0.3$ & 0.7 & 2.2 & $<0.3$ & 0.7 & 11.3 \\
\hline
\end{tabular}

${ }^{1}$ U.S. Environmental Protection Agency Maximum Contaminant Level.

${ }^{2}$ New York State Department of Health Maximum Contaminant Level.

\section{Trace Elements}

The trace elements present in the highest median concentrations in the samples were strontium, with a median of 769 micrograms per liter ( $\mu \mathrm{g} / \mathrm{L}$ ), iron (median $132 \mu \mathrm{g} / \mathrm{L}$ in unfiltered water; $12 \mu \mathrm{g} / \mathrm{L}$ in filtered water), barium (median $126 \mu \mathrm{g} / \mathrm{L}$ ), boron (median $39 \mu \mathrm{g} / \mathrm{L}$ in filtered water), and manganese (median $15.8 \mu \mathrm{g} / \mathrm{L}$ in unfiltered water; $13.7 \mu \mathrm{g} / \mathrm{L}$ in filtered water) (table 8 and appendix table 1-6). The highest detected concentration of a trace element was $23,400 \mu \mathrm{g} / \mathrm{L}$ of strontium in a sample from a bedrock well. The median concentrations of some trace elements were higher in samples from sand and gravel wells than in samples from bedrock wells, for example, copper and lead; the median concentrations of other trace elements were greater in samples from bedrock wells than in samples from sand and gravel wells, including aluminum, barium, boron, iron, lithium, manganese, and strontium.

The concentration of aluminum in three samples from bedrock wells exceeded the low end of the USEPA SDWS for aluminum of $50 \mu \mathrm{g} / \mathrm{L}$, but none exceeded the high end of $200 \mu \mathrm{g} / \mathrm{L}$. The concentration of iron in eight unfiltered and three filtered samples exceeded the NYSDOH MCL and USEPA SDWS of $300 \mu \mathrm{g} / \mathrm{L}$. Three samples had unfiltered iron concentrations greater than 1,000 $\mu \mathrm{g} / \mathrm{L}$; the maximum iron concentration was $14,400 \mu \mathrm{g} / \mathrm{L}$ in an unfiltered sample from a bedrock well. The concentration of manganese in six unfiltered and four filtered samples exceeded the USEPA SDWS of $50 \mu \mathrm{g} / \mathrm{L}$; the concentration of manganese in two unfiltered and two filtered samples exceeded the NYSDOH MCL of $300 \mu \mathrm{g} / \mathrm{L}$. The maximum concentration of manganese, $1,670 \mu \mathrm{g} / \mathrm{L}$, was in an unfiltered sample from a sand and gravel well. Drinking-water standards for antimony, arsenic, barium, beryllium, cadmium, chromium, copper, lead, mercury, selenium, silver, thallium, zinc, and uranium were not exceeded; additionally, cadmium, mercury and thallium were not detected in any of the 21 samples collected (appendix table 1-1). 
Table 8. Drinking-water standards and summary statistics for concentrations of trace elements in groundwater samples from the Mohawk River Basin, New York, 2011.

[All concentrations in micrograms per liter in unfiltered water except as noted. <, less than; --, not applicable]

\begin{tabular}{|c|c|c|c|c|c|c|c|c|c|}
\hline \multirow[b]{3}{*}{ Constituent } & \multicolumn{9}{|c|}{ Summary statistics for concentrations of trace elements } \\
\hline & \multirow{2}{*}{$\begin{array}{l}\text { Drinking- } \\
\text { water } \\
\text { standard }\end{array}$} & \multirow{2}{*}{$\begin{array}{l}\text { Number of } \\
\text { samples } \\
\text { exceeding } \\
\text { standard }\end{array}$} & \multirow{2}{*}{$\begin{array}{c}\text { Median } \\
\text { (all } \\
\text { samples) }\end{array}$} & \multicolumn{3}{|c|}{$\begin{array}{c}\text { Sand and gravel aquifers } \\
\text { (9 samples) }\end{array}$} & \multicolumn{3}{|c|}{$\begin{array}{c}\text { Bedrock aquifers } \\
\text { (12 samples) }\end{array}$} \\
\hline & & & & Minimum & Median & Maximum & Minimum & Median & Maximum \\
\hline Aluminum & $3^{3} 50-200$ & $3-0$ & 3 & $<3$ & $<3$ & 36 & $<3$ & 10 & 194 \\
\hline Antimony & ${ }^{1,2} 6$ & 0 & $<0.2$ & $<0.2$ & $<0.2$ & 0.7 & $<0.2$ & $<0.2$ & 1.2 \\
\hline Arsenic & ${ }^{1,2} 10$ & 0 & 0.43 & 0.14 & 0.43 & 4.9 & 0.15 & 0.40 & 6.2 \\
\hline Barium & ${ }^{1,2} 2,000$ & 0 & 126 & 6.5 & 20.1 & 1,100 & 7.5 & 179 & 968 \\
\hline Beryllium & ${ }^{1,2} 4$ & 0 & $<0.02$ & $<0.02$ & $<0.02$ & $<0.02$ & $<0.02$ & $<0.02$ & 0.02 \\
\hline $\begin{array}{l}\text { Boron, } \\
\text { filtered }\end{array}$ & -- & -- & 39 & 5.8 & 19 & 350 & 1.3 & 165 & 907 \\
\hline Cadmium & ${ }^{1,2} 5$ & 0 & $<0.05$ & $<0.05$ & $<0.05$ & $<0.05$ & $<0.05$ & $<0.05$ & $<0.05$ \\
\hline Chromium & ${ }^{1,2} 100$ & 0 & $<0.21$ & $<0.21$ & 0.23 & 0.46 & $<0.21$ & $<0.21$ & 0.82 \\
\hline Cobalt & -- & -- & 0.03 & $<0.02$ & 0.03 & 0.61 & $<0.02$ & 0.02 & 11.5 \\
\hline Copper & ${ }^{3} 1,000$ & 0 & 4.5 & $<0.70$ & 7.6 & 52.5 & $<0.70$ & $<0.81$ & 20.5 \\
\hline Iron, filtered & ${ }^{2,3} 300$ & 3 & 12 & $<3$ & 4 & 7,620 & $<3$ & 25 & 14,000 \\
\hline Iron & ${ }^{2,3} 300$ & 8 & 132 & $<5$ & $<5$ & 7,700 & $<5$ & 338 & 14,400 \\
\hline Lead & ${ }^{4} 15$ & 0 & 0.22 & $<0.04$ & 0.41 & 1.14 & $<0.04$ & 0.09 & 4.07 \\
\hline Lithium & -- & -- & 8.5 & 0.3 & 6.1 & 91.2 & 3.2 & 60.0 & 989 \\
\hline $\begin{array}{l}\text { Manganese, } \\
\text { filtered }\end{array}$ & $\begin{array}{l}{ }^{2} 300 \\
{ }^{3} 50\end{array}$ & $\begin{array}{l}2 \\
4\end{array}$ & 13.7 & $<0.2$ & 5.6 & 1,620 & 0.3 & 17.2 & 1,040 \\
\hline Manganese & $\begin{aligned}{ }^{2} 300 \\
3_{50}\end{aligned}$ & $\begin{array}{l}2 \\
6\end{array}$ & 15.8 & $<0.4$ & 9.8 & 1,670 & 0.4 & 19.6 & 995 \\
\hline Mercury & ${ }^{1,2} 2$ & 0 & $<0.005$ & $<0.005$ & $<0.005$ & $<0.005$ & $<0.005$ & $<0.005$ & $<0.005$ \\
\hline Molybdenum & -- & -- & 0.4 & $<0.1$ & 0.3 & 5.1 & 0.1 & 0.6 & 8.4 \\
\hline Nickel & -- & -- & 0.38 & $<0.12$ & 0.38 & 2.4 & $<0.12$ & 0.33 & 2.8 \\
\hline Selenium & ${ }^{1,2} 50$ & 0 & 0.10 & $<0.05$ & 0.10 & 0.79 & $<0.05$ & 0.11 & 19.8 \\
\hline Silver & ${ }^{2,3} 100$ & 0 & $<0.01$ & $<0.01$ & $<0.01$ & 0.07 & $<0.01$ & $<0.01$ & 0.02 \\
\hline Strontium & -- & -- & 769 & 54.9 & 229 & 2,910 & 78.1 & 1,410 & 23,400 \\
\hline Thallium & ${ }^{1,2} 2$ & 0 & $<0.06$ & $<0.06$ & $<0.06$ & $<0.06$ & $<0.06$ & $<0.06$ & $<0.06$ \\
\hline Zinc & ${ }^{2,3} 5,000$ & 0 & 7.2 & $<2.4$ & 8.5 & 22.3 & $<2.4$ & 7.0 & 50.4 \\
\hline Uranium & ${ }^{1,2} 30$ & 0 & 0.224 & 0.026 & 0.224 & 1.15 & $<0.014$ & 0.229 & 3.13 \\
\hline
\end{tabular}

${ }^{1}$ U.S. Environmental Protection Agency Maximum Contaminant Level.

${ }^{2}$ New York State Department of Health Maximum Contaminant Level.

${ }^{3}$ U.S. Environmental Protection Agency Secondary Drinking Water Standard.

${ }^{4}$ U.S. Environmental Protection Agency Treatment Technique. 


\section{Pesticides}

Four pesticides and pesticide degradates were detected at trace concentrations in four samples from production wells finished in sand and gravel (appendix table 1-7); all were broadleaf herbicides or their degradates. The pesticide detected with the highest (and estimated) concentration $(0.034 \mu \mathrm{g} / \mathrm{L})$ was CIAT (2-chloro-4-isopropylamino-6-amino-s-triazine), a degradate of atrazine, which was detected in four samples. Atrazine was detected in two samples with a maximum concentration of $0.027 \mu \mathrm{g} / \mathrm{L}$.

Prometon and simazine were detected in one sample each. One sample had detections of four pesticides, one sample had detections of two pesticides, and two samples had detections of one pesticide each, all from sand and gravel wells. No pesticide concentrations exceeded established drinking-water standards; pesticide degradates currently are not regulated.

\section{Volatile Organic Compounds}

VOCs were rarely detected in any of the 21 sampled wells. Three VOCs were detected in samples from two sand and gravel and two bedrock wells (appendix table 1-8). The VOCs detected are a trihalomethane (THM) and two solvents. THMs are byproducts that form when chlorine or bromine are used as disinfectants. Trichloromethane (chloroform) was detected in four samples with a maximum concentration of $4.5 \mu \mathrm{g} / \mathrm{L}$ in a sample from a bedrock well. The concentration of total THMs did not exceed the NYSDOH and USEPA MCLs of $80 \mu \mathrm{g} / \mathrm{L}$. Tetrachloroethene (PERC), a solvent, was detected in a sample from a sand a gravel well with a concentration of $0.2 \mu \mathrm{g} / \mathrm{L}$, which did not exceed the NYSDOH and USEPA MCLs of $5 \mu \mathrm{g} / \mathrm{L}$. Toluene, another solvent, was detected in a sample from a bedrock well with a concentration of $0.1 \mu \mathrm{g} / \mathrm{L}$, which did not exceed the NYSDOH MCL of $5 \mu \mathrm{g} / \mathrm{L}$ or the USEPA MCL of 1,000 $\mu \mathrm{g} / \mathrm{L}$.

\section{Radionuclides}

Gross alpha activity ranged from non-detectable levels to 5.5 picocuries per liter (pCi/L); the median activity was $<2$ pCi/L (table 9 and appendix table 1-9). The gross alpha activity did not exceed the NYSDOH and USEPA MCLs for gross alpha of $15 \mathrm{pCi} / \mathrm{L}$ in any sample. Gross beta activities ranged from non-detectable levels to $5.1 \mathrm{pCi} / \mathrm{L}$. The USEPA and NYSDOH MCLs for gross beta are 4 millirem per year, a dosage determination that requires knowledge of the specific radionuclide sources. The activity units (picocuries per liter) that were used to measure gross beta radioactivity in this study are not comparable to dosage units (millirems per year) without determination of the nuclide sources. Therefore, it is not possible to determine whether any of the samples exceeded the MCL for gross beta radioactivity. Radon-222 activities in the water samples ranged from 22 to 2,320 pCi/L; the median was $141 \mathrm{pCi} / \mathrm{L}$. The highest radon activity was in a sample from a bedrock well finished in sandstone, but the median radon activity in samples from sand and gravel wells $(500 \mathrm{pCi} / \mathrm{L})$ was higher than the median activity in samples from bedrock wells (93 pCi/L). Radon is currently (2013) not regulated in drinking water; however, the USEPA has proposed a two-part standard for radon in drinking water: (1) a $300 \mathrm{pCi} / \mathrm{L}$ MCL for areas that do not implement an indoor-air radon mitigation program and (2) an alternative MCL (AMCL) of 4,000 pCi/L for areas that do (U.S. Environmental Protection Agency, 1999). Activities in 10 of the samples exceeded the proposed MCL, but none exceeded the proposed AMCL. 
Table 9. Drinking-water standards and summary statistics for concentrations of radionuclides in groundwater samples from the Mohawk River Basin, New York, 2011.

[All activities in picocuries per liter in unfiltered water except as noted. mrem/yr, millirem per year; --, not applicable; <, less than]

\begin{tabular}{|c|c|c|c|c|c|c|c|c|c|}
\hline \multirow[b]{3}{*}{ Constituent } & \multicolumn{9}{|c|}{ Summary statistics for radionuclide activities } \\
\hline & \multirow{2}{*}{$\begin{array}{l}\text { Drinking- } \\
\text { water } \\
\text { standard }\end{array}$} & \multirow{2}{*}{$\begin{array}{l}\text { Number of } \\
\text { samples } \\
\text { exceeding } \\
\text { standard }\end{array}$} & \multirow{2}{*}{$\begin{array}{c}\text { Median } \\
\text { (all samples) }\end{array}$} & \multicolumn{3}{|c|}{$\begin{array}{c}\text { Sand and gravel aquifers } \\
\text { (9 samples) }\end{array}$} & \multicolumn{3}{|c|}{$\begin{array}{c}\text { Bedrock aquifers } \\
\text { (12 samples) }\end{array}$} \\
\hline & & & & Minimum & Median & Maximum & Minimum & Median & Maximum \\
\hline $\begin{array}{l}\text { Gross alpha } \\
\text { radioactivity }\end{array}$ & ${ }^{1,2} 15$ & 0 & $<2$ & $<0.33$ & $<0.87$ & 5.5 & $<0.92$ & 1.4 & 4.9 \\
\hline Gross beta radioactivity & $\begin{array}{c}{ }^{1,2} 4 \\
\text { mrem/yr }\end{array}$ & -- & 1.6 & $<0.42$ & 1.4 & 3.3 & $<0.62$ & 2.8 & 5.1 \\
\hline Radon-222 & $\begin{array}{r}3300 \\
44,000\end{array}$ & $\begin{array}{r}10 \\
0\end{array}$ & 141 & 46 & 500 & 710 & 22 & 93 & 2,320 \\
\hline
\end{tabular}

${ }^{1}$ U.S. Environmental Protection Agency Maximum Contaminant Level.

${ }^{2}$ New York State Department of Health Maximum Contaminant Level.

${ }^{3}$ U.S. Environmental Protection Agency Proposed Maximum Contaminant Level.

${ }^{4}$ U.S. Environmental Protection Agency Proposed Alternative Maximum Contaminant Level.

\section{Bacteria}

Coliform bacteria were detected in five samples, all from bedrock wells (appendix table 1-10), with a maximum of 92 colony-forming units (CFUs) per $100 \mathrm{~mL}$. Coliform bacteria were detected in three of the four wells sampled that are finished in carbonate rocks. The NYSDOH and USEPA MCLs for total coliform bacteria are exceeded when 5 percent of samples of finished water collected in 1 month test positive for total coliform (if 40 or more samples are collected per month) or when two samples test positive for total coliform (if fewer than 40 samples are collected per month). Fecal coliform bacteria were detected in one sample (1 CFU/100mL), and Escherichia coli (E. coli) were detected in one sample (2 CFU/100 mL). The heterotrophic plate count ranged from $<1 \mathrm{CFU}$ per $\mathrm{mL}$ to $998 \mathrm{CFU}$ per $\mathrm{mL}$. The USEPA MCL for the heterotrophic plate count is $500 \mathrm{CFU} / \mathrm{mL}$; this limit was exceeded in one sample from a sand and gravel well.

\section{Well sampled in 2002, 2006, and 2011}

Four of the wells sampled in 2011 (wells HE 622, MT 406, OE1460, and SA1501) were sampled previously in 2002 and 2006 as part of this study. Of the 148 constituents and physiochemical properties that samples were analyzed for in 2011, 140 were common to at least 2 years of analyses; the values for the physiochemical properties of the samples and the concentrations of nutrients, major ions, trace elements, radon-222, detected pesticides, pesticide degradates, and VOCs are presented in appendix tables 1-11 through 1-15. Differences between wells were often greater than differences between samples at a single well; however, well MT 406, a bedrock well, showed more variability than other wells. Five pesticides and pesticide degradates were detected in the two of the wells sampled in 2002, 2006, and 2011 (appendix table 1-14); more pesticides were detected in 2006 and 2011 than in 2002. Seven VOCs were detected in three of the wells sampled in 2002, 2006, and 2011, including four THMs - methyl tert-butyl ether (MTBE), tetrachloroethene, and toluene. More VOCs were detected in 2002 and 2006 than in 2011. Coliform bacteria were not detected in any of the four resampled wells (appendix table 1-15). 


\section{Summary}

Groundwater samples were collected during July 2011 from 21 wells in the Mohawk River Basin to characterize the groundwater quality. Sample collection and analysis followed standard USGS procedures and other documented procedures. Samples were analyzed for physical properties and concentrations of dissolved gases, major ions, nutrients, trace elements, pesticides, volatile organic compounds (VOCs), radionuclides, and bacteria. Many of the 148 constituents analyzed for were not detected in any of the samples.

The depths of sand and gravel wells sampled in the Mohawk River Basin range from 28 to $395 \mathrm{ft}$ below land surface; the bedrock wells are 120 to $815 \mathrm{ft}$ deep and typically are completed in shale, sandstone, or carbonate bedrock. Ten of the 21 wells sampled are production wells; 11 are domestic wells. The samples generally indicated good water quality, although properties and concentrations of some constituents - color, $\mathrm{pH}$, sodium, chloride, sulfate, dissolved solids, aluminum, iron, manganese, radon-222, and bacteria - equaled or exceeded primary, secondary, or proposed drinking-water standards. The constituents most frequently detected in concentrations exceeding drinking-water standards were radon-222 (10 samples had concentrations equal to or greater than the U.S. Environmental Protection Agency (USEPA) proposed maximum contaminant level (MCL) of 300 picocuries per liter (pCi/L)), sodium (9 samples had concentrations greater than the USEPA Drinking Water Taste Advisory of 60 milligrams per liter (mg/L)), iron (8 unfiltered samples had concentrations greater than the New York State Department of Health MCL and USEPA secondary drinking-water standard (SDWS) of 300 micrograms per liter $(\mu \mathrm{g} / \mathrm{L})$ ), dissolved solids (7 samples had concentrations greater than the USEPA SDWS of $500 \mathrm{mg} / \mathrm{L}$ ), manganese (6 unfiltered samples had concentrations greater than the USEPA SDWS of $50 \mu \mathrm{g} / \mathrm{L}$ ), and coliform bacteria (5 samples had detections).

Sample $\mathrm{pH}$ was typically near neutral or slightly basic. Methane was detected in 15 of the 21 samples; 2 samples had methane concentrations greater than $28 \mathrm{mg} / \mathrm{L}$. The water typically was very hard, and the median dissolved solids concentration was $436 \mathrm{mg} / \mathrm{L}$. The ions detected in the highest median concentrations were bicarbonate, chloride, calcium, and sodium. The dominant nutrient was nitrate; concentrations of nitrate and nitrite did not exceed established drinking-water standards. Strontium was the trace element with the highest median concentrations; some samples had moderately high (greater than 10,000 $\mu \mathrm{g} / \mathrm{L}$ ) concentrations of strontium or iron. Four pesticides and pesticide degradates were detected in four samples from sand and gravel wells; all were trace-level detections of broadleaf herbicides or their degradates. Three VOCs were detected in four samples, including chloroform, tetrachloroethene, and toluene. Radon-222 activities in 10 samples exceeded a proposed MCL, but none exceeded the proposed AMCL. Coliform bacteria were detected in five samples. Fecal coliform and Escherichia coli bacteria were detected in one sample each.

\section{References Cited}

American Public Health Association, 1998, Standard methods for the examination of water and wastewater (20th ed.): Washington, D.C., American Public Health Association, American Water Works Association, and Water Environment Federation [variously paged].

ASTM International, 2006, D5072-98(2006), Standard test method for radon in drinking water: ASTM International, accessed December 28, 2006, at http://www.astm.org.

Butch, G.K., Murray, P.M., Hebert, G.J., and Weigel, J.F., 2003, Water resources data, New York, water year 2002: U.S. Geological Survey Water-Data Report NY-02-1, p. 502-520.

Cadwell, D.H., 1991, Surficial geologic map of New York: New York State Museum Map and Chart Series no. 40, Lower Hudson sheet, scale 1:250,000. 
Childress, C.J.O., Foreman, W.T., Connor, B.F., and Maloney, T.J., 1999, New reporting procedures based on long-term method detection levels and some considerations for interpretations of waterquality data provided by the U.S. Geological Survey National Water Quality Laboratory: U.S. Geological Survey Open-File Report 99-193, 19 p.

Connor, B.F., Rose, D.L., Noriega, M.C., Murtagh, L.K., and Abney, S.R., 1998, Methods of analysis by the U.S. Geological Survey National Water Quality Laboratory-Determination of 86 volatile organic compounds in water by gas chromatography/mass spectrometry, including detections less than reporting limits: U.S. Geological Survey Open-File Report 97-829, 78 p., accessed December 9, 2011, at http://nwql.usgs.gov/Public/rpt.shtml?OFR-97-829.

Eckhardt, D.A., Reddy, J.E., and Shaw, S.B., 2009, Groundwater quality in central New York, 2007: U.S. Geological Survey Open-File Report 2009-1257, 40 p., accessed August 15, 2011, at http://pubs.usgs.gov/of/2009/1257/.

Eckhardt, D.A., Reddy, J.E., and Tamulonis, K.L., 2007, Ground-water quality in the Genesee River Basin, New York, 2005-06: U.S. Geological Survey Open-File Report 2007-1093, 26 p., accessed August 15, 2011, at http://pubs.usgs.gov/of/2007/1093/.

Eckhardt, D.A., Reddy, J.E., and Tamulonis, K.L., 2008, Ground-water quality in western New York, 2006: U.S. Geological Survey Open-File Report 2008-1140, 36 p., accessed August 15, 2011, at http://pubs.usgs.gov/of/2008/1140/.

Eltschlager, K.K., Hawkins, J.W., Ehler, W.C., and Baldassare, F.B., 2001, Technical measures for the investigation and mitigation of fugitive methane hazards in areas of coal mining: Pittsburgh, Pa., U.S. Department of the Interior, Office of Surface Mining Reclamation and Enforcement, 124 p.

Fisher, D.W., Isachsen, Y.W., and Rickard, L.V., 1970, Geologic map of New York State: New York State Museum Map and Chart Series no. 15, Lower Hudson sheet, scale 1:250,000.

Fishman, M.J., ed., 1993, Methods of analysis by the U.S. Geological Survey National Water Quality Laboratory-Determination of inorganic and organic constituents in water and fluvial sediments: U.S. Geological Survey Open-File Report 93-125, 217 p., December 9, 2011, at http://pubs.usgs.gov/of/1993/0125/report.pdf.

Furlong, E.T., Anderson, B.D., Werner, S.L., Soliven, P.P., Coffey, L.J., and Burkhardt, M.R., 2001, Methods of analysis by the U.S. Geological Survey National Water Quality Laboratory-

Determination of pesticides in water by graphitized carbon-based solid-phase extraction and highperformance liquid chromatography/mass spectrometry: U.S. Geological Survey Water-Resources Investigations Report 01-4134, 73 p., accessed December 9, 2011, at http://nwql.usgs.gov/WRIR-014134.shtml.

Garbarino, J.R., and Damrau, D.L., 2001, Methods of analysis by the U.S. Geological Survey National Water Quality Laboratory-Determination of organic plus inorganic mercury in filtered and unfiltered natural water with cold vapor-atomic fluorescence spectrometry: U.S. Geological Survey WaterResources Investigations Report 01-4132, 16 p., accessed December 9, 2011, at http://nwql.usgs.gov/WRIR-01-4132.shtml.

Garbarino, J.R., Kanagy, L.K., and Cree, M.E., 2006, Determination of elements in natural-water, biota, sediment and soil samples using collision/reaction cell inductively coupled plasma-mass spectrometry: U.S. Geological Survey Techniques and Methods, book 5, chap. B1, 88 p., accessed December 9, 2011, at http://pubs.usgs.gov/tm/2006/tm5b1/.

Garbarino, J.R., and Struzeski, T.M., 1998, Methods of analysis by the U.S. Geological Survey National Water Quality Laboratory-Determination of elements in whole-water digests using inductively coupled plasma-optical emission spectrometry and inductively coupled plasma-mass spectrometry: 
U.S. Geological Survey Open-File Report 98-165, 101 p., accessed December 9, 2011, at http://nwql.usgs.gov/OFR-98-165.shtml.

Hammond, D.S., Heath, R.C., and Waller, R.M., 1978, Ground-water data on the Hudson River Basin, New York: U. S. Geological Survey Open File Report 78-710, 18 p., accessed December 9, 2011, at http://pubs.usgs.gov/of/1978/0710/report.pdf.

Hem, J.D., 1985, Study and interpretation of the chemical characteristics of natural water (3d ed.): U.S. Geological Survey Water-Supply Paper 2254, 264 p.

Hetcher-Aguila, K.K., 2005, Ground-water quality in the Chemung River Basin, New York, 2003: U.S. Geological Survey Open-File Report 2004-1329, 19 p., accessed August 15, 2011, at http://ny.water.usgs.gov/pubs/of/of041329/.

Hetcher-Aguila, K.K., and Eckhardt, D.A., 2006, Ground-water quality in the upper Susquehanna River Basin, New York, 2004: U.S. Geological Survey Open-File Report 2006-1161, 21 p., accessed August 15, 2011, at http://pubs.usgs.gov/of/2006/1161/.

Hoffman, G.L., Fishman, M.J., and Garbarino, J.R., 1996, Methods of analysis by the U.S. Geological Survey National Water Quality Laboratory-In-bottle acid digestion of whole-water samples: U.S. Geological Survey Open-File Report 96-225, 28 p., accessed December 9, 2011, at http://pubs.usgs.gov/of/1996/0225/report.pdf.

Isachsen, Y.W., Landing, E., Lauber, J.M., Rickard, L.V., and Rogers, W.B., eds., 2000, Geology of New York-A simplified account (2d ed.): Albany, N.Y., New York State Museum/Geological Survey, 294 p.

Kenny, J.F., Barber, N.L., Hutson, S.S., Linsey, K.S., Lovelace, J.K., and Maupin, M.A., 2009, Estimated use of water in the United States in 2005: U.S. Geological Survey Circular 1344, 52 p.

New York State Department of Health, 2011, New York State Health Department public water systems regulations: Albany, N.Y. [variously paged], accessed December 9, 2011, at http://www.health.ny.gov/regulations/nycrr/title_10/part_5/subpart_5-1_tables.htm.

Nystrom, E.A., 2006, Ground-water quality in the Lake Champlain Basin, New York, 2004: U.S. Geological Survey Open-File Report 2006-1088, 22 p., accessed August 15, 2011, at http://pubs.usgs.gov/of/2006/1088/.

Nystrom, E.A., 2007a, Ground-water quality in the St. Lawrence River Basin, New York, 2005-06: U.S. Geological Survey Open-File Report 2007-1066, 33 p., accessed August 15, 2011, at http://pubs.usgs.gov/of/2007/1066/.

Nystrom, E.A., 2007b, Ground-water quality in the Delaware River Basin, New York, 2001 \& 2005-06: U.S. Geological Survey Open-File Report 2007-1098, 36 p., accessed August 15, 2011, at http://pubs.usgs.gov/of/2007/1098/.

Nystrom, E.A., 2008, Ground-water quality in the Mohawk River Basin, New York, 2006: U.S. Geological Survey Open-File Report 2008-1086, 33 p., accessed August 15, 2011, at http://pubs.usgs.gov/of/2008/1086/.

Nystrom, E.A., 2009, Groundwater quality in the Upper Hudson River Basin, New York, 2007: U.S. Geological Survey Open-File Report 2009-1240, 37 p., accessed August 15, 2011, at http://pubs.usgs.gov/of/2009/1240/.

Nystrom, E.A., 2010, Groundwater quality in the Lower Hudson River Basin, New York, 2008: U.S. Geological Survey Open-File Report 2010-1197, 39 p., accessed August 15, 2011, at http://pubs.usgs.gov/of/2010/1197/.

Nystrom, E.A., 2011, Groundwater quality in the Lake Champlain Basin, New York, 2009: U.S. Geological Survey Open-File Report 2011-1180, 42 p., accessed August15, 2011, at http://pubs.usgs.gov/of/2011/1180/. 
Nystrom, E.A., 2012, Groundwater quality in the Delaware and St. Lawrence River Basins, New York, 2010: U.S. Geological Survey Open-File Report 2011-1320, 58 p., accessed January 17, 2012, at http://pubs.usgs.gov/of/2011/1320/.

Patton, C.J., and Truitt, E.P., 2000, Methods of analysis by the U.S. Geological Survey National Water Quality Laboratory-Determination of ammonium plus organic nitrogen by a Kjeldahl digestion method and an automated photometric finish that includes digest cleanup by gas diffusion: U.S. Geological Survey Open-File Report 00-170, 31 p., accessed December 9, 2011, at http://pubs.usgs.gov/of/2000/0170/report.pdf.

Reddy, J.E., and Risen, A.J., 2012, Groundwater quality in the Upper Susquehanna River Basin, 2009: U.S. Geological Survey Open-File Report 2012-1045, 30 p., accessed April 11, 2012, at http://pubs.usgs.gov/of/2012/1045/.

Reddy, J.E., 2012, Groundwater quality in the Genesee River Basin, 2010: U.S. Geological Survey Open-File Report 2012-1135, 29 p., accessed August 7, 2012, at http://pubs.usgs.gov/of/2012/1135/.

Reynolds, 1990, Availability of ground water from unconsolidated deposits in the Mohawk River basin, New York: U.S. Geological Survey Water-Resources Investigations Report 88-4091, 9 plates.

Risen, A.J., and Reddy, J.E., 2011a, Groundwater quality in the Chemung River Basin, 2008: U.S. Geological Survey Open-File Report 2011-1112, 25 p., accessed August 15, 2011, at http://pubs.usgs.gov/of/2011/1112/.

Risen, A.J., and Reddy, J.E., 2011b, Groundwater quality in the Eastern Lake Ontario Basin New York, 2008: U.S. Geological Survey Open-File Report 2011-1074, 32 p., accessed August 15, 2011, at http://pubs.usgs.gov/of/2011/1074/.

Sandstrom, M.W., Stroppel, M.E., Foreman, W.T., and Schroeder, M.P., 2001, Methods of analysis by the U.S. Geological Survey National Water Quality Laboratory-Determination of moderate-use pesticides and selected degradates in water by C-18 solid-phase extraction and gas chromatography/mass spectrometry: U.S. Geological Survey Water-Resources Investigations Report 01-4098, 70 p., accessed December 9, 2011, at http://nwql.usgs.gov/Public/WRIR-01-4098.shtml.

Struzeski, T.M., DeGiacomo, W.J., and Zayhowski, E.J., 1996, Methods of analysis by the U.S. Geological Survey National Water Quality Laboratory-Determination of dissolved aluminum and boron in water by inductively coupled plasma-atomic emission spectrometry: U.S. Geological Survey Open-File Report 96-149, 17 p., accessed December 9, 2011, at http://pubs.usgs.gov/of/1996/0149/report.pdf.

U.S. Environmental Protection Agency, 1980, Prescribed procedures for measurement of radioactivity in drinking water: EPA 600/4-80-032, accessed March 16, 2010, at http://water.epa.gov/scitech/methods/cwa/bioindicators/upload/2007_07_10_methods_method_900_0. pdf.

U.S. Environmental Protection Agency, 1997, Guidelines for preparation of the comprehensive state water quality assessments (305(b) Reports) and electronic updates: Washington, D.C., U.S. Environmental Protection Agency, Office of Water, EPA 841-B-97-002A and EPA 841-B-97-002B, PL95-217, $271 \mathrm{p}$.

U.S. Environmental Protection Agency, 1999, Proposed radon in drinking water rule: Washington, D.C., U.S. Environmental Protection Agency, Office of Water, EPA 815-F-99-006, 6 p.

U.S. Environmental Protection Agency, 2009, National primary drinking water standards and national secondary drinking water standards: Washington, D.C., U.S. Environmental Protection Agency, Office of Water, EPA 816-F-09-0004, 6 p., accessed March 25, 2009, at http://www.epa.gov/safewater/consumer/pdf/mcl.pdf. 
U.S. Geological Survey, variously dated, National field manual for the collection of water-quality data: U.S. Geological Survey Techniques of Water-Resource Investigations, book 9, chaps. A1-A9 [variously paged].

U.S. Geological Survey, 2006, Collection of water samples (ver. 2.0): U.S. Geological Survey Techniques of Water-Resources Investigations, book 9, chap. A4, September, accessed March 4, 2010, at http://pubs.water.usgs.gov/twri9A4/.

Vogelmann, J.E., Howard, S.M., Yang, L., Larson, C.R., Wylie, B.K., and Van Driel, J.N., 2001, Completion of the 1990's National Land Cover Data Set for the conterminous United States: Photogrammetric Engineering and Remote Sensing, v. 67, p. 650-662.

Wilde, F.D., ed., 2004, Cleaning of equipment for water sampling (ver. 2.0): U.S. Geological Survey Techniques of Water-Resources Investigations, book 9, chap. A3, April, accessed March 4, 2010, at http://pubs.water.usgs.gov/twri9A3/.

Wilde, F.D., Radtke, D.B., Gibs, Jacob, and Iwatsubo, R.T., eds., 2004 with updates through 2009, Processing of water samples (version 2.2): U.S. Geological Survey Techniques of Water-Resources Investigations, book 9, chap. A5, April, accessed March 4, 2010, at http://pubs.water.usgs.gov/twri9A5/.

Zaugg, S.D., Sandstrom, M.W., Smith, S.G., and Fehlberg, K.M., 1995, Methods of analysis by the U.S. Geological Survey National Water Quality Laboratory-Determination of pesticides in water by C-18 solid-phase extraction and capillary-column gas chromatography/mass spectrometry with selected-ion monitoring: U.S. Geological Survey Open-File Report 95-181, 60 p., accessed December 9, 2011, at http://pubs.usgs.gov/of/1995/0181/report.pdf. 


\section{Appendix: Results of Water-Sample Analyses}

The following tables summarize results of the chemical analyses of the 21 samples collected in the Mohawk River Basin in New York during July 2011.

Table 1-1. Constituents that were not detected in groundwater samples collected in the Mohawk River Basin, New York, 2011.

Table 1-2. Physiochemical properties of groundwater samples collected in the Mohawk River Basin, New York, 2011.

Table 1-3. Concentrations of dissolved gases in groundwater samples collected in the Mohawk River Basin, New York, 2011.

Table 1-4. Concentrations of major ions in groundwater samples collected in the Mohawk River Basin, New York, 2011.

Table 1-5. Concentrations of nutrients and organic carbon in groundwater samples collected in the Mohawk River Basin, New York, 2011.

Table 1-6. Concentrations of trace elements in groundwater samples collected in the Mohawk River Basin, New York, 2011.

Table 1-7. Concentrations of pesticides detected in groundwater samples collected in the Mohawk River Basin, New York, 2011. .

Table 1-8. Concentrations of volatile organic compounds detected in groundwater samples collected in the Mohawk River Basin, New York, 2011.......

Table 1-9. Activities of radionuclides in groundwater samples from the Mohawk River Basin, New York, 2011...

Table 1-10. Bacteria in groundwater samples collected in the Mohawk River Basin, New York, 2011.

Table 1-11. Physiochemical properties and concentrations of nutrients in groundwater samples collected in the Mohawk River Basin, New York, 2002, 2006, and 2011.

Table 1-12. Concentrations of major ions in groundwater samples collected in the Mohawk River Basin, New York, 2002, 2006, and 2011......

Table 1-13. Concentrations of trace elements and radionuclides in groundwater samples in the Mohawk River Basin, New York, 2002, 2006, and 2011.

Table 1-14. Concentrations of pesticides and of volatile organic compounds detected in groundwater samples collected in the Mohawk River Basin, New York, 2002, 2006, and 2011.

Table 1-15. Bacteria in groundwater samples collected in the Mohawk River Basin, New York, 2006 and 2011... 
Table 1-1. Constituents that were not detected in groundwater samples collected from 21 wells in the Mohawk River Basin, New York, 2011.

[NWIS, National Water Information System]

\begin{tabular}{lll}
\hline $\begin{array}{l}\text { U.S. Geological } \\
\text { Survey NWIS } \\
\text { parameter code }\end{array}$ & \multicolumn{1}{c}{ Constituent } & $\begin{array}{c}\text { Laboratory } \\
\text { reporting } \\
\text { level }\end{array}$ \\
\hline \multicolumn{2}{l}{ Trace elements in } & unfiltered water, in micrograms per liter \\
\hline 01027 & Cadmium & 0.05 \\
71900 & Mercury & 0.005 \\
01059 & Thallium & 0.06 \\
\hline
\end{tabular}

Pesticides in filtered water, in micrograms per liter

\begin{tabular}{lll}
\hline 82660 & 2,6-Diethylaniline & 0.006 \\
49260 & Acetochlor & 0.010 \\
46342 & Alachlor & 0.008 \\
34253 & alpha-HCH & 0.004 \\
82686 & Azinphos-methyl & 0.120 \\
82673 & Benfluralin & 0.014 \\
04028 & Butylate & 0.004 \\
82680 & Carbaryl & 0.060 \\
82674 & Carbofuran & 0.060 \\
38933 & Chlorpyrifos & 0.004 \\
82687 & cis-Permethrin & 0.010 \\
04041 & Cyanazine & 0.022 \\
82682 & DCPA & 0.008 \\
62170 & Desulfinylfipronil & 0.012 \\
39572 & Diazinon & 0.006 \\
39381 & Dieldrin & 0.008 \\
82677 & Disulfoton & 0.04 \\
82668 & EPTC & 0.006 \\
82663 & Ethalfluralin & 0.006 \\
82672 & Ethoprop & 0.016 \\
62169 & Desulfinylfipronil & 0.029 \\
62167 & amide & 0.012 \\
62168 & Fipronil sulfide & 0.024 \\
62166 & Fipronil sulfone & 0.018 \\
04095 & Fipronil & 0.005 \\
39341 & Fonofos & 0.004 \\
82666 & Lindane & 0.060 \\
39532 & Linuron & 0.016 \\
82667 & Malathion & 0.008 \\
39415 & Methyl parathion & 0.020 \\
82630 & Metribuzin & 0.012 \\
82671 & Molinate & 0.004 \\
82684 & Napropamide & 0.008 \\
34653 & p,p'-DDE & 0.002 \\
39542 & Parathion & 0.020 \\
82669 & Pebulate & 0.016 \\
82683 & Pendimethalin & 0.012 \\
82664 & Phorate & 0.020 \\
& & \\
\hline & & \\
\hline
\end{tabular}

\begin{tabular}{|c|c|c|}
\hline $\begin{array}{l}\text { U.S. Geological } \\
\text { Survey NWIS } \\
\text { parameter code }\end{array}$ & Constituent & $\begin{array}{c}\text { Laboratory } \\
\text { reporting } \\
\text { level } \\
\end{array}$ \\
\hline \multicolumn{3}{|c|}{ Pesticides in filtered water, in micrograms per liter--continued } \\
\hline 82676 & Propyzamide & 0.004 \\
\hline 04024 & Propachlor & 0.006 \\
\hline 82679 & Propanil & 0.010 \\
\hline 82685 & Propargite & 0.02 \\
\hline 82670 & Tebuthiuron & 0.03 \\
\hline 82665 & Terbacil & 0.024 \\
\hline 82675 & Terbufos & 0.02 \\
\hline 82681 & Thiobencarb & 0.016 \\
\hline 82678 & Triallate & 0.005 \\
\hline 82661 & Trifluralin & 0.018 \\
\hline \multicolumn{3}{|c|}{$\begin{array}{l}\text { Volatile organic compounds in unfiltered water, } \\
\text { in micrograms per liter }\end{array}$} \\
\hline 34506 & 1,1,1-Trichloroethane & 0.1 \\
\hline 77652 & $\begin{array}{l}\text { 1,1,2-Trichloro-1,2,2- } \\
\text { trifluoroethane }\end{array}$ & 0.1 \\
\hline 34496 & 1,1-Dichloroethane & 0.1 \\
\hline 34501 & 1,1-Dichloroethene & 0.1 \\
\hline 34536 & 1,2-Dichlorobenzene & 0.1 \\
\hline 32103 & 1,2-Dichloroethane & 0.2 \\
\hline 34541 & 1,2-Dichloropropane & 0.1 \\
\hline 34566 & 1,3-Dichlorobenzene & 0.1 \\
\hline 34571 & 1,4-Dichlorobenzene & 0.1 \\
\hline 34030 & Benzene & 0.1 \\
\hline 32101 & Bromodichloromethane & 0.1 \\
\hline 32104 & Tribromomethane & 0.2 \\
\hline 34301 & Chlorobenzene & 0.1 \\
\hline 77093 & cis-1,2-Dichloroethene & 0.1 \\
\hline 32105 & Dibromochloromethane & 0.2 \\
\hline 34668 & Dichlorodifluoromethane & 0.2 \\
\hline 34423 & Dichloromethane & 0.2 \\
\hline 81576 & Diethyl ether & 0.2 \\
\hline 81577 & Diisopropyl ether & 0.2 \\
\hline 34371 & Ethylbenzene & 0.1 \\
\hline 50005 & Methyl tert-pentyl ether & 0.2 \\
\hline 85795 & $m$-Xylene plus $p$-xylene & 0.2 \\
\hline 77135 & o-Xylene & 0.1 \\
\hline 77128 & Styrene & 0.1 \\
\hline 50004 & tert-Butyl ethyl ether & 0.1 \\
\hline 78032 & Methyl tert-butyl ether & 0.2 \\
\hline 32102 & Tetrachloromethane & 0.2 \\
\hline 34546 & trans-1,2-Dichloroethene & 0.1 \\
\hline 39180 & Trichloroethene & 0.1 \\
\hline 34488 & Trichlorofluoromethane & 0.2 \\
\hline 39175 & Vinyl chloride & 0.2 \\
\hline
\end{tabular}


Table 1-2. Physiochemical properties of groundwater samples collected in the Mohawk River Basin, New York, 2011.

$\left[\mu \mathrm{S} / \mathrm{cm} @ 25^{\circ} \mathrm{C}\right.$, microsiemens per centimeter at 25 degrees Celsius; (00080), U.S. Geological Survey National Water Information System parameter code; <, less than; U, not detected; M, detected but not quantified. Bold values exceed one or more drinking-water standards. Well locations are shown in figures 2 and 3]

\begin{tabular}{|c|c|c|c|c|c|}
\hline $\begin{array}{c}\text { Well } \\
\text { number }^{1}\end{array}$ & $\begin{array}{c}\text { Color, } \\
\text { platinum-cobalt } \\
\text { units } \\
(00080)\end{array}$ & $\begin{array}{c}\mathrm{pH}, \\
\text { field, } \\
\text { standard units } \\
(00400)\end{array}$ & $\begin{array}{c}\text { Specific } \\
\text { conductance, } \\
\text { field, } \\
\mu S / \mathrm{cm} @ 25^{\circ} \mathrm{C} \\
(00095)\end{array}$ & $\begin{array}{c}\text { Water } \\
\text { temperature, } \\
\text { field, } \\
\text { degrees Celsius } \\
(00010)\end{array}$ & $\begin{array}{l}\text { Hydrogen } \\
\text { sulfide odor } \\
\text { field } \\
\text { (71875) }\end{array}$ \\
\hline \multicolumn{6}{|c|}{ Sand and gravel wells } \\
\hline HE 622 & $<1$ & 7.3 & 874 & 11.4 & $\mathrm{U}$ \\
\hline HE1929 & $<1$ & 8.0 & 207 & 9.6 & $\mathrm{U}$ \\
\hline OE1460 & $<1$ & 7.2 & 923 & 13.6 & $\mathrm{U}$ \\
\hline OE1468 & $<1$ & 7.3 & 835 & 9.6 & $\mathrm{U}$ \\
\hline SA1501 & $<1$ & 7.3 & 353 & 11.7 & $\mathrm{U}$ \\
\hline SA2259 & $<1$ & 7.2 & 480 & 15.2 & $\mathrm{U}$ \\
\hline SN1366 & 5 & 7.6 & 1,470 & 13.3 & M \\
\hline SO 605 & $<1$ & 6.8 & 194 & 11.5 & $\mathrm{U}$ \\
\hline SO 814 & $<1$ & 7.6 & 1,100 & 10.6 & $\mathrm{U}$ \\
\hline \multicolumn{6}{|c|}{ Bedrock wells } \\
\hline A667 & $<1$ & 7.6 & 590 & 13.6 & $\mathrm{M}$ \\
\hline FU1611 & 175 & 6.5 & 286 & 11.5 & $\mathrm{U}$ \\
\hline G 837 & $<1$ & 8.9 & 309 & 9.6 & M \\
\hline HE1459 & $<1$ & 7.3 & 510 & 10.7 & $\mathrm{U}$ \\
\hline HE1480 & $<1$ & 8.0 & 526 & 11.7 & M \\
\hline MT 406 & $<1$ & 7.5 & 961 & 10.3 & M \\
\hline OE2876 & 2 & 8.2 & 1,260 & 14.4 & M \\
\hline SA2806 & 8 & 7.7 & 453 & 15.7 & M \\
\hline SN1131 & 10 & 7.5 & 773 & 16.0 & $\mathrm{U}$ \\
\hline SO1037 & $<1$ & 8.1 & 308 & 11.4 & $\mathrm{U}$ \\
\hline SO1487 & $<1$ & 7.5 & 542 & 13.1 & $\mathrm{U}$ \\
\hline SO1658 & $<1$ & 7.5 & 1,450 & 9.4 & $\mathrm{U}$ \\
\hline
\end{tabular}

${ }^{1}$ A, Albany County; FU, Fulton County; G, Greene County; HE, Herkimer County; MT, Montgomery County; OE, Oneida County; SA, Saratoga County; SN, Schenectady County; SO, Schoharie County. 
Table 1-3. Concentrations of dissolved gases in groundwater samples collected in the Mohawk River Basin, New York, 2011.

[mg/L, milligrams per liter; (00300), U.S. Geological Survey National Water Information System parameter code; <, less than. Well locations are shown in figures 2 and 3]

\begin{tabular}{|c|c|c|c|c|c|c|c|c|c|}
\hline \multirow{2}{*}{$\begin{array}{c}\text { Well } \\
\text { number }^{1}\end{array}$} & \multirow{2}{*}{$\begin{array}{l}\text { Dissolved } \\
\text { oxygen, } \\
\text { field, } \\
\mathrm{mg} / \mathrm{L} \\
(00300) \\
\end{array}$} & \multicolumn{2}{|c|}{$\begin{array}{c}\text { Carbon } \\
\text { dioxide, } \\
\text { laboratory, } \\
\mathrm{mg} / \mathrm{L} \\
(00405) \\
\end{array}$} & \multicolumn{2}{|c|}{$\begin{array}{c}\text { Argon, } \\
\text { laboratory, } \\
\text { mg/L } \\
(82043)\end{array}$} & \multicolumn{2}{|c|}{$\begin{array}{c}\text { Dissolved nitrogen } \\
\text { gas, } \\
\text { laboratory, } \\
\text { mg/L } \\
(00597) \\
\end{array}$} & \multicolumn{2}{|c|}{$\begin{array}{c}\text { Methane, } \\
\text { laboratory, } \\
\text { mg/L } \\
(85574)\end{array}$} \\
\hline & & Bottle 1 & Bottle 2 & Bottle 1 & Bottle 2 & Bottle 1 & Bottle 2 & Bottle 1 & Bottle 2 \\
\hline \multicolumn{10}{|c|}{ Sand and gravel wells } \\
\hline HE 622 & 4.3 & 19.6 & 19.6 & 0.6990 & 0.7008 & 19.06 & 19.04 & $<0.001$ & $<0.001$ \\
\hline HE1929 & 6.8 & 1.7 & 1.8 & 0.7332 & 0.7330 & 19.63 & 19.52 & 0.0013 & 0.0015 \\
\hline OE1460 & 5.4 & 37.8 & 37.7 & 0.6949 & 0.6927 & 18.36 & 18.19 & 0.0088 & 0.0084 \\
\hline OE1468 & 4.3 & 24.9 & 25.0 & 0.7348 & 0.7384 & 22.00 & 22.18 & $<0.001$ & $<0.001$ \\
\hline SA1501 & 3.9 & 22.2 & 21.9 & 0.7033 & 0.7019 & 19.87 & 19.83 & 0.143 & 0.067 \\
\hline SA2259 & 1.6 & 23.8 & 23.3 & 0.7728 & 0.7859 & 23.57 & 24.24 & $<0.001$ & $<0.001$ \\
\hline SN1366 & 0.2 & 20.4 & 19.9 & 1.171 & 1.164 & 39.85 & 39.49 & 0.0030 & 0.0028 \\
\hline SO 605 & 0.5 & 17.5 & 17.5 & 0.6101 & 0.6179 & 16.66 & 16.95 & $<0.001$ & $<0.001$ \\
\hline SO 814 & $<0.3$ & 16.4 & 16.7 & 0.7598 & 0.7619 & 23.35 & 23.39 & 0.013 & 0.013 \\
\hline \multicolumn{10}{|c|}{ Bedrock wells } \\
\hline A667 & $<0.3$ & 13.9 & 14.0 & 0.7407 & 0.7497 & 18.81 & 19.32 & 35.6 & 38.3 \\
\hline FU1611 & $<0.3$ & 47.1 & 47.0 & 0.8120 & 0.8097 & 23.05 & 22.95 & 0.632 & 0.631 \\
\hline G 837 & $<0.3$ & 0.3 & 0.3 & 0.9605 & 0.9661 & 30.22 & 30.21 & 8.33 & 8.25 \\
\hline HE1459 & 1.0 & 15.9 & 16.0 & 0.7510 & 0.7443 & 21.43 & 21.29 & $<0.001$ & 0.0014 \\
\hline HE1480 & $<0.3$ & 6.2 & 6.2 & 0.8858 & 0.8960 & 26.05 & 26.48 & 5.10 & 5.11 \\
\hline MT 406 & $<0.3$ & 36.3 & 35.8 & 0.9487 & 0.9521 & 33.37 & 33.62 & 0.021 & 0.019 \\
\hline OE2876 & $<0.3$ & 1.7 & 3.0 & 0.6700 & 0.6571 & 16.81 & 16.16 & 42.0 & 44.3 \\
\hline SA2806 & $<0.3$ & 9.3 & 9.3 & 0.6392 & 0.6387 & 17.39 & 17.51 & 23.7 & 24.2 \\
\hline SN1131 & $<0.3$ & 15.4 & 15.7 & 0.8202 & 0.8256 & 23.53 & 23.72 & 0.515 & 0.510 \\
\hline SO1037 & $<0.3$ & 2.6 & 2.6 & 0.8148 & 0.8057 & 24.69 & 24.32 & 0.054 & 0.052 \\
\hline SO1487 & $<0.3$ & 17.1 & 16.9 & 0.8077 & 0.8051 & 23.67 & 23.65 & $<0.001$ & $<0.001$ \\
\hline SO1658 & 2.2 & 29.3 & 29.8 & 0.7544 & 0.7549 & 21.10 & 20.98 & $<0.001$ & $<0.001$ \\
\hline
\end{tabular}

${ }^{1}$ A, Albany County; FU, Fulton County; G, Greene County; HE, Herkimer County; MT, Montgomery County; OE, Oneida County; SA, Saratoga County; SN, Schenectady County; SO, Schoharie County. 
Table 1-4. Concentrations of major ions in groundwater samples collected in the Mohawk River Basin, New York, 2011.

[mg/L, milligrams per liter; $\mathrm{CaCO}_{3}$, calcium carbonate; (00900), U.S. Geological Survey National Water Information System parameter code; <, less than; ${ }^{\circ} \mathrm{C}$; degrees Celsius. Bold values exceed one or more drinking-water standards. Well locations are shown in figures 2 and 3$]$

\begin{tabular}{|c|c|c|c|c|c|c|c|}
\hline $\begin{array}{c}\text { Well } \\
\text { number1 }^{1}\end{array}$ & $\begin{array}{l}\text { Hardness, } \\
\text { filtered, } \\
\text { mg/L as } \\
\mathrm{CaCO}_{3} \\
(00900)\end{array}$ & $\begin{array}{l}\text { Calcium, } \\
\text { filtered, } \\
\text { mg/L } \\
(00915)\end{array}$ & $\begin{array}{c}\text { Magnesium, } \\
\text { filtered, } \\
\text { mg/L } \\
(00925)\end{array}$ & $\begin{array}{l}\text { Potassium, } \\
\text { filtered, } \\
\text { mg/L } \\
(00935)\end{array}$ & $\begin{array}{c}\text { Sodium, } \\
\text { filtered, } \\
\text { mg/L } \\
(00930)\end{array}$ & $\begin{array}{c}\text { Acid } \\
\text { neutralizing } \\
\text { capacity, } \\
\text { unfiltered, } \\
\text { mg/L as } \\
\mathrm{CaCO}_{3} \\
(90410)\end{array}$ & $\begin{array}{c}\text { Alkalinity, } \\
\text { filtered, } \\
\text { incremental } \\
\text { titration, } \\
\text { field, } \\
\text { mg/L as } \\
\mathrm{CaCO}_{3} \\
(39086)\end{array}$ \\
\hline \multicolumn{8}{|c|}{ Sand and gravel wells } \\
\hline HE 622 & 284 & 87.6 & 15.9 & 3.40 & 68.7 & 226 & 212 \\
\hline HE1929 & 103 & 27.1 & 8.57 & 0.47 & 2.51 & 105 & 94 \\
\hline OE1460 & 357 & 98.0 & 27.4 & 1.92 & 56.6 & 247 & 269 \\
\hline OE1468 & 347 & 97.8 & 25.1 & 1.46 & 40.0 & 240 & 230 \\
\hline SA1501 & 204 & 63.6 & 11.0 & 2.02 & 15.2 & 176 & 160 \\
\hline SA2259 & 301 & 73.8 & 28.3 & 0.89 & 10.1 & 205 & 243 \\
\hline SN1366 & 520 & 119 & 53.8 & 2.14 & 150 & 347 & 289 \\
\hline SO 605 & 72.5 & 24.2 & 2.91 & 0.83 & 9.91 & 65 & 48 \\
\hline SO 814 & 386 & 120 & 21.1 & 1.02 & 64.6 & 241 & 211 \\
\hline \multicolumn{8}{|c|}{ Bedrock wells } \\
\hline A667 & 198 & 41.1 & 23.0 & 2.17 & 94.7 & 268 & 243 \\
\hline FU1611 & 79.6 & 27.2 & 2.82 & 1.01 & 11.7 & 80 & 78 \\
\hline G 837 & 21.0 & 7.14 & 0.781 & 0.29 & 88.5 & 122 & 107 \\
\hline HE1459 & 260 & 85.6 & 11.3 & 1.28 & 40.6 & 130 & 169 \\
\hline HE1480 & 75.2 & 17.9 & 7.44 & 6.68 & 89.0 & 275 & 157 \\
\hline MT 406 & 385 & 113 & 25.0 & 4.10 & 53.3 & 294 & 255 \\
\hline OE2876 & 96.6 & 18.9 & 12.0 & 5.08 & 273 & 172 & 159 \\
\hline SA2806 & 160 & 36.7 & 16.6 & 4.40 & 57.9 & 264 & 224 \\
\hline SN1131 & 315 & 63.8 & 37.7 & 1.91 & 81.5 & 274 & 251 \\
\hline SO1037 & 53.0 & 15.2 & 3.63 & 0.59 & 50.4 & 147 & 126 \\
\hline SO1487 & 193 & 45.9 & 19.0 & 3.04 & 43.3 & 255 & 223 \\
\hline SO1658 & 636 & 214 & 24.7 & 1.19 & 70.7 & 264 & 221 \\
\hline
\end{tabular}

\footnotetext{
${ }^{1}$ A, Albany County; FU, Fulton County; G, Greene County; HE, Herkimer County; MT, Montgomery County; OE, Oneida County; SA, Saratoga County; SN, Schenectady County; SO, Schoharie County.
} 
Table1-4. Concentrations of major ions in groundwater samples collected in the Mohawk River Basin, New York, 2011-Continued

[mg/L, milligrams per liter; $\mathrm{CaCO}_{3}$, calcium carbonate; (00900), U.S. Geological Survey National Water Information System parameter code; <, less than; ${ }^{\circ} \mathrm{C}$; degrees Celsius. Bold values exceed one or more drinking-water standards. Well locations are shown in figures 2 and 3 ]

\begin{tabular}{|c|c|c|c|c|c|c|}
\hline $\begin{array}{c}\text { Well } \\
\text { number }\end{array}$ & $\begin{array}{l}\text { Bicarbonate, } \\
\text { filtered, } \\
\text { incremental } \\
\text { titration, } \\
\text { field, } \\
\mathrm{mg} / \mathrm{L} \\
(00453)\end{array}$ & $\begin{array}{c}\text { Chloride, } \\
\text { filtered, } \\
\text { mg/L } \\
(00940)\end{array}$ & $\begin{array}{c}\text { Fluoride, } \\
\text { filtered, } \\
\text { mg/L } \\
(00950)\end{array}$ & $\begin{array}{c}\text { Silica, } \\
\text { filtered, } \\
\mathrm{mg} / \mathrm{L} \\
(00955)\end{array}$ & $\begin{array}{c}\text { Sulfate, } \\
\text { filtered, } \\
\mathrm{mg} / \mathrm{L} \\
(00945)\end{array}$ & $\begin{array}{c}\text { Dissolved } \\
\text { solids, } \\
\text { dried at } 180^{\circ} \mathrm{C}, \\
\text { filtered, } \\
\mathrm{mg} / \mathrm{L} \\
(70300)\end{array}$ \\
\hline \multicolumn{7}{|c|}{ Sand and gravel wells } \\
\hline HE 622 & 258 & 112 & 0.06 & 7.34 & 33.2 & 500 \\
\hline HE1929 & 114 & 3.01 & $<0.04$ & 6.08 & 5.01 & 133 \\
\hline OE1460 & 327 & 101 & 0.05 & 6.11 & 18.0 & 507 \\
\hline OE1468 & 279 & 89.5 & $<0.04$ & 7.57 & 32.1 & 473 \\
\hline SA1501 & 194 & 24.6 & 0.20 & 13.0 & 16.1 & 302 \\
\hline SA2259 & 295 & 21.5 & 0.05 & 11.5 & 32.4 & 351 \\
\hline SN1366 & 352 & 9.83 & 0.55 & 13.3 & 453 & 1,090 \\
\hline SO 605 & 59 & 13.1 & 0.43 & 5.10 & 12.2 & 125 \\
\hline SO 814 & 257 & 188 & 0.06 & 13.5 & 31.9 & 764 \\
\hline \multicolumn{7}{|c|}{ Bedrock wells } \\
\hline A667 & 295 & 92.1 & 0.53 & 8.94 & 18.1 & 444 \\
\hline FU1611 & 95 & 17.8 & 0.26 & 13.0 & 9.15 & 170 \\
\hline G 837 & 127 & 64.9 & 0.48 & 7.45 & 4.36 & 230 \\
\hline HE1459 & 205 & 97.2 & 0.20 & 17.1 & 19.4 & 436 \\
\hline HE1480 & 190 & 10.4 & 0.79 & 9.50 & 1.31 & 305 \\
\hline MT 406 & 310 & 89.0 & 0.32 & 7.38 & 79.8 & 577 \\
\hline OE2876 & 191 & 393 & 1.55 & 7.78 & 4.81 & 843 \\
\hline SA2806 & 272 & 19.9 & 0.37 & 13.1 & 14.0 & 314 \\
\hline SN1131 & 305 & 112 & 0.60 & 17.5 & 35.4 & 540 \\
\hline SO1037 & 153 & 7.63 & 0.36 & 8.81 & 11.4 & 186 \\
\hline SO1487 & 272 & 13.3 & 0.53 & 10.9 & 19.2 & 319 \\
\hline SO1658 & 270 & 110 & 0.36 & 8.70 & 388 & 1,040 \\
\hline
\end{tabular}

${ }^{1}$ A, Albany County; FU, Fulton County; G, Greene County; HE, Herkimer County; MT, Montgomery County; OE, Oneida County; SA, Saratoga County; SN, Schenectady County; SO, Schoharie County. 
Table 1-5. Concentrations of nutrients and organic carbon in groundwater samples collected in the Mohawk River Basin, New York, 2011.

[N, nitrogen; P, phosphorus; mg/L, milligrams per liter; (00623), U.S. Geological Survey National Water Information System parameter code; <, less than. Well locations are shown in figures 2 and 3]

\begin{tabular}{|c|c|c|c|c|c|c|c|}
\hline $\begin{array}{c}\text { Well } \\
\text { number }^{1}\end{array}$ & $\begin{array}{l}\text { Ammonia } \\
\text { plus } \\
\text { organic-N, } \\
\text { filtered, } \\
\text { mg/L as N } \\
\text { (00623) }\end{array}$ & $\begin{array}{l}\text { Ammonia, } \\
\text { filtered, } \\
\text { mg/L as } N \\
(00608)\end{array}$ & $\begin{array}{l}\text { Nitrate plus } \\
\text { nitrite, } \\
\text { filtered, } \\
\text { mg/L as N } \\
\text { (00631) }\end{array}$ & $\begin{array}{c}\text { Nitrate, } \\
\text { filtered, } \\
\text { mg/L as N } \\
(00618)\end{array}$ & $\begin{array}{c}\text { Nitrite, } \\
\text { filtered, } \\
\text { mg/L as N } \\
(00613)\end{array}$ & $\begin{array}{c}\text { Ortho- } \\
\text { phosphate, } \\
\text { filtered, } \\
\text { mg/L as P } \\
\text { (00671) }\end{array}$ & $\begin{array}{c}\text { Organic } \\
\text { carbon, } \\
\text { unfiltered, } \\
\text { mg/L } \\
(00680)\end{array}$ \\
\hline \multicolumn{8}{|c|}{ Sand and gravel wells } \\
\hline HE 622 & 0.07 & $<0.010$ & 2.38 & 2.38 & $<0.001$ & 0.007 & 0.6 \\
\hline HE1929 & $<0.05$ & $<0.010$ & 0.28 & 0.281 & 0.001 & 0.006 & 0.4 \\
\hline OE1460 & $<0.05$ & $<0.010$ & 2.41 & 2.41 & $<0.001$ & 0.005 & 0.7 \\
\hline OE1468 & $<0.05$ & $<0.010$ & 2.39 & 2.39 & $<0.001$ & 0.007 & $<0.3$ \\
\hline SA1501 & 0.25 & 0.164 & 0.04 & 0.038 & $<0.001$ & 0.011 & 2.2 \\
\hline SA2259 & 0.07 & $<0.010$ & 3.48 & 3.48 & $<0.001$ & 0.012 & 1.4 \\
\hline SN1366 & 0.84 & 0.715 & $<0.02$ & $<0.016$ & 0.004 & 0.011 & 0.4 \\
\hline SO 605 & $<0.05$ & $<0.010$ & 0.46 & 0.456 & 0.001 & 0.007 & 1.0 \\
\hline SO 814 & 0.15 & 0.100 & $<0.02$ & $<0.020$ & $<0.001$ & 0.022 & 0.7 \\
\hline \multicolumn{8}{|c|}{ Bedrock wells } \\
\hline A667 & 1.5 & 1.29 & $<0.02$ & $<0.020$ & $<0.001$ & 0.155 & 0.6 \\
\hline FU1611 & 0.80 & 0.556 & $<0.02$ & $<0.013$ & 0.007 & 0.007 & 11.3 \\
\hline G 837 & 0.05 & 0.059 & $<0.02$ & $<0.020$ & $<0.001$ & 0.033 & 0.5 \\
\hline HE1459 & $<0.05$ & $<0.010$ & 0.55 & 0.550 & 0.002 & 0.011 & 0.8 \\
\hline HE1480 & 2.4 & 2.07 & $<0.02$ & $<0.019$ & 0.001 & 0.010 & 0.3 \\
\hline MT 406 & 0.44 & 0.339 & $<0.02$ & $<0.020$ & $<0.001$ & 0.008 & 1.4 \\
\hline OE2876 & 1.7 & 1.61 & $<0.02$ & $<0.020$ & $<0.001$ & 0.011 & $<0.3$ \\
\hline SA2806 & 0.70 & 0.612 & $<0.02$ & $<0.020$ & $<0.001$ & 0.036 & 0.9 \\
\hline SN1131 & 0.29 & 0.243 & $<0.02$ & $<0.020$ & $<0.001$ & 0.014 & 1.1 \\
\hline SO1037 & $<0.05$ & $<0.010$ & 0.05 & 0.049 & $<0.001$ & 0.016 & $<0.3$ \\
\hline SO1487 & 1.2 & 0.990 & 0.48 & 0.477 & $<0.001$ & 0.008 & $<0.3$ \\
\hline SO1658 & 0.23 & 0.011 & 0.16 & 0.136 & 0.020 & 0.007 & 1.0 \\
\hline
\end{tabular}

${ }^{1}$ A, Albany County; FU, Fulton County; G, Greene County; HE, Herkimer County; MT, Montgomery County; OE, Oneida County; SA, Saratoga County; SN, Schenectady County; SO, Schoharie County. 
Table 1-6. Concentrations of trace elements in groundwater samples collected in the Mohawk River Basin, New York, 2011.

[ $\mu \mathrm{g} / \mathrm{L}$, micrograms per liter; (01105), U.S. Geological Survey National Water Information System parameter code; <, less than. Bold values exceed one or more drinking-water standards. Well locations are shown in figures 2 and 3$]$

\begin{tabular}{|c|c|c|c|c|c|c|c|c|}
\hline $\begin{array}{c}\text { Well } \\
\text { number }{ }^{1}\end{array}$ & $\begin{array}{c}\text { Aluminum, } \\
\text { unfiltered, } \\
\mu \mathrm{g} / \mathrm{L} \\
(01105) \\
\end{array}$ & $\begin{array}{c}\text { Antimony, } \\
\text { unfiltered, } \\
\mu \mathrm{g} / \mathrm{L} \\
(01097) \\
\end{array}$ & $\begin{array}{c}\text { Arsenic, } \\
\text { unfiltered, } \\
\mu \mathrm{g} / \mathrm{L} \\
(01002)\end{array}$ & $\begin{array}{c}\text { Barium, } \\
\text { unfiltered, } \\
\mu \mathrm{g} / \mathrm{L} \\
(01007)\end{array}$ & $\begin{array}{c}\text { Beryllium, } \\
\text { unfiltered, } \\
\mu \mathrm{g} / \mathrm{L} \\
(01012)\end{array}$ & $\begin{array}{c}\text { Boron, } \\
\text { filtered, } \\
\mu \mathrm{g} / \mathrm{L} \\
(01020)\end{array}$ & $\begin{array}{c}\text { Chromium, } \\
\text { unfiltered, } \\
\mu \mathrm{g} / \mathrm{L} \\
(01034) \\
\end{array}$ & $\begin{array}{c}\text { Cobalt, } \\
\text { unfiltered, } \\
\mu \mathrm{g} / \mathrm{L} \\
(01037)\end{array}$ \\
\hline \multicolumn{9}{|c|}{ Sand and gravel wells } \\
\hline HE 622 & $<3$ & $<0.2$ & 1.0 & 206 & $<0.02$ & 25 & 0.29 & 0.02 \\
\hline HE1929 & 14 & $<0.2$ & 0.14 & 6.5 & $<0.02$ & 5.8 & $<0.21$ & 0.02 \\
\hline OE1460 & $<3$ & $<0.2$ & 0.37 & 85.7 & $<0.02$ & 19 & $<0.21$ & 0.05 \\
\hline OE1468 & $<3$ & $<0.2$ & 0.45 & 205 & $<0.02$ & 16 & $<0.21$ & 0.03 \\
\hline SA1501 & $<3$ & $<0.2$ & 0.43 & 20.1 & $<0.02$ & 22 & 0.46 & 0.61 \\
\hline SA2259 & 36 & $<0.2$ & 0.42 & 12.2 & $<0.02$ & 11 & 0.29 & 0.31 \\
\hline SN1366 & $<3$ & $<0.2$ & 2.6 & 11.0 & $<0.02$ & 350 & 0.38 & 0.10 \\
\hline SO 605 & $<3$ & $<0.2$ & 0.16 & 18.4 & $<0.02$ & 11 & $<0.21$ & $<0.02$ \\
\hline SO 814 & $<3$ & 0.7 & 4.9 & 1,100 & $<0.02$ & 39 & 0.23 & 0.02 \\
\hline \multicolumn{9}{|c|}{ Bedrock wells } \\
\hline A667 & 18 & $<0.2$ & 0.25 & 968 & $<0.02$ & 376 & 0.32 & $<0.02$ \\
\hline FU1611 & 80 & $<0.2$ & 0.18 & 7.5 & $<0.02$ & 1.3 & 0.48 & 11.5 \\
\hline G 837 & 7 & $<0.2$ & 6.2 & 157 & $<0.02$ & 99 & 0.29 & $<0.02$ \\
\hline HE1459 & 5 & $<0.2$ & 0.34 & 48.5 & $<0.02$ & 28 & $<0.21$ & 0.02 \\
\hline HE1480 & 124 & 0.7 & 0.15 & 245 & 0.02 & 907 & $<0.21$ & 0.07 \\
\hline MT 406 & $<3$ & $<0.2$ & 0.80 & 126 & $<0.02$ & 121 & $<0.21$ & 0.03 \\
\hline OE2876 & 13 & 0.4 & 0.47 & 535 & $<0.02$ & 564 & $<0.21$ & $<0.02$ \\
\hline SA2806 & 194 & $<0.2$ & 0.26 & 694 & $<0.02$ & 170 & 0.82 & 0.05 \\
\hline SN1131 & 3 & $<0.2$ & 4.0 & 110 & $<0.02$ & 160 & $<0.21$ & 0.14 \\
\hline SO1037 & 16 & $<0.2$ & 4.0 & 22.0 & $<0.02$ & 188 & $<0.21$ & 0.02 \\
\hline SO1487 & $<3$ & $<0.2$ & 0.23 & 201 & $<0.02$ & 319 & $<0.21$ & 0.02 \\
\hline SO1658 & $<3$ & 1.2 & 0.79 & 215 & $<0.02$ & 27 & 0.55 & 0.05 \\
\hline
\end{tabular}

\footnotetext{
${ }^{1}$ A, Albany County; FU, Fulton County; G, Greene County; HE, Herkimer County; MT, Montgomery County; OE, Oneida County; SA, Saratoga County; SN, Schenectady County; SO, Schoharie County.
} 
Table1-6. Concentrations of trace elements in groundwater samples collected in the Mohawk River Basin, New York, 2011-Continued

[ $\mu \mathrm{g} / \mathrm{L}$, micrograms per liter; (01105), U.S. Geological Survey National Water Information System parameter code; <, less than. Bold values exceed one or more drinking-water standards. Well locations are shown in figures 2 and 3]

\begin{tabular}{|c|c|c|c|c|c|c|c|}
\hline $\begin{array}{c}\text { Well } \\
\text { number }^{1}\end{array}$ & $\begin{array}{c}\text { Copper, } \\
\text { unfiltered, } \\
\mu \mathrm{g} / \mathrm{L} \\
(01042) \\
\end{array}$ & $\begin{array}{c}\text { Iron, } \\
\text { filtered, } \\
\mu \mathrm{g} / \mathrm{L} \\
(01046)\end{array}$ & $\begin{array}{c}\text { Iron, } \\
\text { unfiltered, } \\
\mu \mathrm{g} / \mathrm{L} \\
(01045)\end{array}$ & $\begin{array}{c}\text { Lead, } \\
\text { unfiltered, } \\
\mu \mathrm{g} / \mathrm{L} \\
(01051)\end{array}$ & $\begin{array}{c}\text { Lithium, } \\
\text { unfiltered, } \\
\mu \mathrm{g} / \mathrm{L} \\
(\mathbf{0 1 1 3 2})\end{array}$ & $\begin{array}{c}\text { Manganese, } \\
\text { filtered, } \\
\mu \mathrm{g} / \mathrm{L} \\
(01056) \\
\end{array}$ & $\begin{array}{c}\text { Manganese, } \\
\text { unfiltered, } \\
\mu \mathrm{g} / \mathrm{L} \\
(01055) \\
\end{array}$ \\
\hline \multicolumn{8}{|c|}{ Sand and gravel wells } \\
\hline HE 622 & 7.7 & $<3$ & $<5$ & 0.41 & 6.1 & 0.4 & 0.5 \\
\hline HE1929 & 6.1 & 6 & 738 & 1.14 & 0.3 & 5.6 & 9.8 \\
\hline OE1460 & 9.6 & 4 & $<5$ & 0.16 & 7.6 & 0.4 & 0.5 \\
\hline OE1468 & 7.6 & $<3$ & $<5$ & 0.58 & 6.7 & $<0.2$ & $<0.4$ \\
\hline SA1501 & 1.7 & 3 & $<5$ & 1.11 & 4.3 & 1,620 & 1,670 \\
\hline SA2259 & 52.5 & 12 & 111 & 0.49 & 0.8 & 13.7 & 15.3 \\
\hline SN1366 & $<0.70$ & 7,620 & 7,700 & $<0.04$ & 91.2 & 268 & 282 \\
\hline SO 605 & 4.5 & $<3$ & $<5$ & 0.09 & 0.5 & $<0.2$ & $<0.4$ \\
\hline SO 814 & 11.5 & 175 & 195 & 0.23 & 75.8 & 232 & 246 \\
\hline \multicolumn{8}{|c|}{ Bedrock wells } \\
\hline A667 & $<0.70$ & 31 & 487 & 0.04 & 360 & 33.4 & 35.6 \\
\hline FU1611 & 20.5 & 14,000 & 14,400 & 4.07 & 3.6 & 1,040 & 995 \\
\hline G 837 & $<0.70$ & 6 & 22 & 0.06 & 40.3 & 27.4 & 29.5 \\
\hline HE1459 & 5.5 & 11 & 78 & 0.25 & 7.2 & 0.3 & 0.4 \\
\hline HE1480 & 0.81 & 43 & 237 & 0.08 & 353 & 13.3 & 15.8 \\
\hline MT 406 & $<0.70$ & 102 & 132 & $<0.04$ & 10.9 & 17.1 & 19.1 \\
\hline OE2876 & 5.5 & 271 & 440 & $<0.04$ & 989 & 7.7 & 9.1 \\
\hline SA2806 & $<0.70$ & 19 & 684 & 0.10 & 79.7 & 45.0 & 50.5 \\
\hline SN1131 & 5.7 & 1,340 & 1,410 & 0.35 & 91.2 & 45.2 & 50.5 \\
\hline SO1037 & 2.7 & 17 & 458 & 0.33 & 8.5 & 17.2 & 20.2 \\
\hline SO1487 & $<0.70$ & $<3$ & $<5$ & 0.22 & 118 & 4.5 & 5.0 \\
\hline SO1658 & $<0.70$ & 9 & 24 & $<0.04$ & 3.2 & 0.5 & 0.9 \\
\hline
\end{tabular}

\footnotetext{
${ }^{1}$ A, Albany County; FU, Fulton County; G, Greene County; HE, Herkimer County; MT, Montgomery County; OE, Oneida
} County; SA, Saratoga County; SN, Schenectady County; SO, Schoharie County. 
Table1-6. Concentrations of trace elements in groundwater samples collected in the Mohawk River Basin, New York, 2011-Continued

[ $\mu \mathrm{g} / \mathrm{L}$, micrograms per liter; (01105), U.S. Geological Survey National Water Information System parameter code; <, less than. Bold values exceed one or more drinking-water standards. Well locations are shown in figures 2 and 3]

\begin{tabular}{|c|c|c|c|c|c|c|c|}
\hline $\begin{array}{c}\text { Well } \\
\text { number }^{1}\end{array}$ & $\begin{array}{c}\text { Molybdenum, } \\
\text { unfiltered, } \\
\mu \mathrm{g} / \mathrm{L} \\
(01062) \\
\end{array}$ & $\begin{array}{c}\text { Nickel, } \\
\text { unfiltered, } \\
\mu \mathrm{g} / \mathrm{L} \\
(01067) \\
\end{array}$ & $\begin{array}{c}\text { Selenium, } \\
\text { unfiltered, } \\
\mu \mathrm{g} / \mathrm{L} \\
(01147) \\
\end{array}$ & $\begin{array}{c}\text { Silver, } \\
\text { unfiltered, } \\
\mu \mathrm{g} / \mathrm{L} \\
(01077) \\
\end{array}$ & $\begin{array}{c}\text { Strontium, } \\
\text { unfiltered, } \\
\mu \mathrm{g} / \mathrm{L} \\
(01082) \\
\end{array}$ & $\begin{array}{c}\text { Zinc, } \\
\text { unfiltered, } \\
\mu \mathrm{g} / \mathrm{L} \\
(01092) \\
\end{array}$ & $\begin{array}{c}\text { Uranium, } \\
\text { unfiltered, } \\
\mu \mathrm{g} / \mathrm{L} \\
(28011) \\
\end{array}$ \\
\hline \multicolumn{8}{|c|}{ Sand and gravel wells } \\
\hline HE 622 & 0.1 & 0.21 & 0.79 & $<0.01$ & 618 & $<2.4$ & 0.208 \\
\hline HE1929 & 0.1 & $<0.12$ & $<0.05$ & $<0.01$ & 79.1 & $<2.4$ & 0.073 \\
\hline OE1460 & $<0.1$ & 0.44 & 0.09 & 0.07 & 229 & 8.5 & 0.137 \\
\hline OE1468 & 0.3 & 0.60 & 0.12 & $<0.01$ & 169 & 15.2 & 0.423 \\
\hline SA1501 & 1.2 & 2.4 & 0.12 & $<0.01$ & 235 & $<2.4$ & 0.224 \\
\hline SA2259 & 0.3 & 2.0 & 0.12 & $<0.01$ & 205 & 22.3 & 0.717 \\
\hline SN1366 & 5.1 & 0.12 & $<0.05$ & $<0.01$ & 2,910 & $<2.4$ & 1.15 \\
\hline SO 605 & 0.1 & 0.18 & 0.10 & $<0.01$ & 54.9 & 11.5 & 0.026 \\
\hline SO 814 & 0.6 & 0.38 & $<0.05$ & $<0.01$ & 1,330 & 15.0 & 0.533 \\
\hline \multicolumn{8}{|c|}{ Bedrock wells } \\
\hline A667 & 0.1 & 0.49 & 9.1 & $<0.01$ & 4,280 & 50.4 & $<0.014$ \\
\hline FU1611 & 0.2 & 2.8 & 0.25 & $<0.01$ & 78.1 & 6.7 & 0.074 \\
\hline G 837 & 1.8 & $<0.12$ & 3.6 & $<0.01$ & 152 & 22.1 & $<0.014$ \\
\hline HE1459 & 0.4 & 0.24 & 0.06 & $<0.01$ & 824 & 11.7 & 0.257 \\
\hline HE1480 & 0.1 & 0.22 & $<0.05$ & $<0.01$ & 1,460 & $<2.4$ & 0.032 \\
\hline MT 406 & 2.8 & 0.50 & 0.08 & $<0.01$ & 1,810 & 10.7 & 1.48 \\
\hline OE2876 & 5.9 & $<0.12$ & 0.05 & $<0.01$ & 2,730 & $<2.4$ & 0.165 \\
\hline SA2806 & 0.2 & 0.81 & 19.8 & $<0.01$ & 1,360 & $<2.4$ & 0.201 \\
\hline SN1131 & 7.7 & 0.42 & 0.08 & $<0.01$ & 769 & 7.2 & 0.874 \\
\hline SO1037 & 8.4 & $<0.12$ & 0.20 & $<0.01$ & 111 & $<2.4$ & 3.13 \\
\hline SO1487 & 0.6 & 0.18 & 0.12 & $<0.01$ & 3,700 & $<2.4$ & 0.279 \\
\hline SO1658 & 0.6 & 0.80 & 0.10 & 0.02 & 23,400 & 23.0 & 0.643 \\
\hline
\end{tabular}
${ }^{1}$ A, Albany County; FU, Fulton County; G, Greene County; HE, Herkimer County; MT, Montgomery County; OE, Oneida
County; SA, Saratoga County; SN, Schenectady County; SO, Schoharie County. 
Table 1-7. Concentrations of pesticides detected in groundwater samples collected in the Mohawk River Basin, New York, 2011.

[ $\mu \mathrm{g} / \mathrm{L}$, micrograms per liter; CIAT, 2-chloro-4-isopropylamino-6-amino-s-triazine; (04040), U.S. Geological Survey National Water Information System parameter code; <, less than; E, estimated concentration; M, presence verified but not quantified. Well locations are shown in figures 2 and 3]

\begin{tabular}{|c|c|c|c|c|}
\hline $\begin{array}{c}\text { Well } \\
\text { number }^{1}\end{array}$ & $\begin{array}{c}\text { CIAT, } \\
\text { filtered, } \\
\mu \mathrm{g} / \mathrm{L} \\
(04040)\end{array}$ & $\begin{array}{c}\text { Atrazine, } \\
\text { filtered, } \\
\mu \mathrm{g} / \mathrm{L} \\
(39632)\end{array}$ & $\begin{array}{c}\text { Prometon, } \\
\text { filtered, } \\
\mu \mathrm{g} / \mathrm{L} \\
(04037) \\
\end{array}$ & $\begin{array}{c}\text { Simazine, } \\
\text { filtered, } \\
\mu \mathrm{g} / \mathrm{L} \\
(04035)\end{array}$ \\
\hline \multicolumn{5}{|c|}{ Sand and gravel wells } \\
\hline HE 622 & E0.001 & $<0.008$ & $<0.01$ & $<0.006$ \\
\hline HE1929 & $<0.006$ & $<0.008$ & $<0.01$ & $<0.006$ \\
\hline OE1460 & E0.034 & 0.027 & M & 0.002 \\
\hline OE1468 & E0.005 & $<0.008$ & $<0.01$ & $<0.006$ \\
\hline SA1501 & $<0.006$ & $<0.008$ & $<0.01$ & $<0.006$ \\
\hline SA2259 & $<0.006$ & $<0.008$ & $<0.01$ & $<0.006$ \\
\hline SN1366 & $<0.006$ & $<0.008$ & $<0.01$ & $<0.006$ \\
\hline SO 605 & E0.005 & 0.003 & $<0.01$ & $<0.006$ \\
\hline SO 814 & $<0.006$ & $<0.008$ & $<0.01$ & $<0.006$ \\
\hline \multicolumn{5}{|c|}{ Bedrock wells } \\
\hline A667 & $<0.006$ & $<0.008$ & $<0.01$ & $<0.006$ \\
\hline FU1611 & $<0.006$ & $<0.008$ & $<0.01$ & $<0.006$ \\
\hline G 837 & $<0.006$ & $<0.008$ & $<0.01$ & $<0.006$ \\
\hline HE1459 & $<0.006$ & $<0.008$ & $<0.01$ & $<0.006$ \\
\hline HE1480 & $<0.006$ & $<0.008$ & $<0.01$ & $<0.006$ \\
\hline MT 406 & $<0.006$ & $<0.008$ & $<0.01$ & $<0.006$ \\
\hline OE2876 & $<0.006$ & $<0.008$ & $<0.01$ & $<0.006$ \\
\hline SA2806 & $<0.006$ & $<0.008$ & $<0.01$ & $<0.006$ \\
\hline SN1131 & $<0.006$ & $<0.008$ & $<0.01$ & $<0.006$ \\
\hline SO1037 & $<0.006$ & $<0.008$ & $<0.01$ & $<0.006$ \\
\hline SO1487 & $<0.006$ & $<0.008$ & $<0.01$ & $<0.006$ \\
\hline SO1658 & $<0.006$ & $<0.008$ & $<0.01$ & $<0.006$ \\
\hline
\end{tabular}

\footnotetext{
${ }^{1}$ A, Albany County; FU, Fulton County; G, Greene County; HE, Herkimer County; MT, Montgomery County; OE, Oneida County; SA, Saratoga County; SN, Schenectady County; SO, Schoharie County.
} 
Table 1-8. Concentrations of volatile organic compounds detected in groundwater samples collected in the Mohawk River Basin, New York, 2011.

[ $\mu \mathrm{g} / \mathrm{L}$, micrograms per liter; (34475), U.S. Geological Survey National Water Information System parameter code; <, less than. Well locations are shown in figures 2 and 3]

\begin{tabular}{|c|c|c|c|}
\hline $\begin{array}{c}\text { Well } \\
\text { number }^{1}\end{array}$ & $\begin{array}{c}\text { Tetra- } \\
\text { chloro- } \\
\text { ethene, } \\
\text { unfiltered, } \\
\mu \mathrm{g} / \mathrm{L} \\
(34475) \\
\end{array}$ & $\begin{array}{c}\text { Toluene, } \\
\text { unfiltered, } \\
\mu \mathrm{g} / \mathrm{L} \\
(34010)\end{array}$ & $\begin{array}{c}\text { Trichloro- } \\
\text { methane, } \\
\text { unfiltered, } \\
\mu \mathrm{g} / \mathrm{L} \\
(32106)\end{array}$ \\
\hline \multicolumn{4}{|c|}{ Sand and gravel wells } \\
\hline HE 622 & $<0.1$ & $<0.1$ & $<0.1$ \\
\hline HE1929 & $<0.1$ & $<0.1$ & $<0.1$ \\
\hline OE1460 & 0.2 & $<0.1$ & 0.1 \\
\hline OE1468 & $<0.1$ & $<0.1$ & $<0.1$ \\
\hline SA1501 & $<0.1$ & $<0.1$ & $<0.1$ \\
\hline SA2259 & $<0.1$ & $<0.1$ & $<0.1$ \\
\hline SN1366 & $<0.1$ & $<0.1$ & $<0.1$ \\
\hline SO 605 & $<0.1$ & $<0.1$ & 0.2 \\
\hline SO 814 & $<0.1$ & $<0.1$ & $<0.1$ \\
\hline \multicolumn{4}{|c|}{ Bedrock wells } \\
\hline A667 & $<0.1$ & $<0.1$ & $<0.1$ \\
\hline FU1611 & $<0.1$ & 0.1 & 4.5 \\
\hline G 837 & $<0.1$ & $<0.1$ & $<0.1$ \\
\hline HE1459 & $<0.1$ & $<0.1$ & $<0.1$ \\
\hline HE1480 & $<0.1$ & $<0.1$ & 0.2 \\
\hline MT 406 & $<0.1$ & $<0.1$ & $<0.1$ \\
\hline OE2876 & $<0.1$ & $<0.1$ & $<0.1$ \\
\hline SA2806 & $<0.1$ & $<0.1$ & $<0.1$ \\
\hline SN1131 & $<0.1$ & $<0.1$ & $<0.1$ \\
\hline SO1037 & $<0.1$ & $<0.1$ & $<0.1$ \\
\hline SO1487 & $<0.1$ & $<0.1$ & $<0.1$ \\
\hline SO1658 & $<0.1$ & $<0.1$ & $<0.1$ \\
\hline
\end{tabular}

${ }^{1}$ A, Albany County; FU, Fulton County; G, Greene County; HE, Herkimer County; MT, Montgomery County; OE, Oneida County; SA, Saratoga County; SN, Schenectady County; SO, Schoharie County. 
Table 1-9. Activities of radionuclides in groundwater samples from the Mohawk River Basin, New York, 2011. [pCi/L, picocuries per liter; (01519), USGS National Water Information System parameter code; <, less than. Bold values equal or exceed one or more existing or proposed drinking-water standard. Well locations are shown in figures 2 and 3]

\begin{tabular}{|c|c|c|c|}
\hline $\begin{array}{c}\begin{array}{c}\text { Well } \\
\text { number }^{1}\end{array} \\
\end{array}$ & $\begin{array}{l}\text { Gross alpha } \\
\text { radioactivity, } \\
\text { unfiltered, } \\
\text { pCi/L } \\
(01519)\end{array}$ & $\begin{array}{c}\text { Gross beta } \\
\text { radioactivity, } \\
\text { unfiltered, } \\
\text { pCi/L } \\
(85817) \\
\end{array}$ & $\begin{array}{c}\text { Radon-222, } \\
\text { unfiltered, } \\
\text { pCi/L } \\
(82303) \\
\end{array}$ \\
\hline \multicolumn{4}{|c|}{ Sand and gravel wells } \\
\hline HE 622 & $<1.5$ & 3.3 & 470 \\
\hline HE1929 & $<0.33$ & $<0.42$ & 126 \\
\hline OE1460 & $<0.87$ & 1.6 & 560 \\
\hline OE1468 & $<1.4$ & 1.6 & 510 \\
\hline SA1501 & $<0.75$ & 1.3 & 500 \\
\hline SA2259 & $<0.83$ & 0.7 & 670 \\
\hline SN1366 & 5.5 & 2.0 & 400 \\
\hline SO 605 & $<0.42$ & 0.6 & 710 \\
\hline SO 814 & 2.0 & 1.4 & 46 \\
\hline \multicolumn{4}{|c|}{ Bedrock wells } \\
\hline A667 & 4.6 & 4.8 & 115 \\
\hline FU1611 & 1.2 & 0.8 & 80 \\
\hline G 837 & 1.5 & $<0.62$ & 300 \\
\hline HE1459 & $<0.95$ & 1.0 & 141 \\
\hline HE1480 & $<0.92$ & 5.1 & 22 \\
\hline MT 406 & $<2$ & 4.0 & 106 \\
\hline OE2876 & 3.2 & 4.3 & 42 \\
\hline SA2806 & 2.1 & 4.5 & 47 \\
\hline SN1131 & $<1.4$ & 2.5 & 74 \\
\hline SO1037 & 4.9 & 3.0 & 2,320 \\
\hline SO1487 & 1.2 & 2.7 & 35 \\
\hline SO1658 & 2.7 & $<1.3$ & 300 \\
\hline
\end{tabular}

${ }^{1}$ A, Albany County; FU, Fulton County; G, Greene County; HE, Herkimer County; MT, Montgomery County; OE, Oneida County; SA, Saratoga County; SN, Schenectady County; SO, Schoharie County. 
Table 1-10. Bacteria in groundwater samples collected in the Mohawk River Basin, New York, 2011.

[CFU, colony-forming unit; mL, milliliter; (31691), U.S. Geological Survey National Water Information System parameter code; <, less than. Bold values indicate detections of coliform bacteria. Well locations are shown in figures 2 and 3]

\begin{tabular}{|c|c|c|c|c|}
\hline $\begin{array}{c}\text { Well } \\
\text { number }^{1}\end{array}$ & $\begin{array}{c}\text { Escherichia } \\
\text { coli, } \\
\text { defined } \\
\text { substrate, } \\
\text { unfiltered, } \\
\text { CFU/100mL } \\
(31691)\end{array}$ & $\begin{array}{c}\text { Fecal } \\
\text { coliform, } \\
\text { membrane } \\
\text { filtration, } \\
\text { unfiltered, } \\
\text { CFU/100mL } \\
(61215)\end{array}$ & $\begin{array}{l}\text { Heterotrophic } \\
\text { plate count, } \\
\text { unfiltered, } \\
\text { CFU/mL } \\
\text { (31692) }\end{array}$ & $\begin{array}{c}\text { Total } \\
\text { coliform, } \\
\text { membrane } \\
\text { filtration, } \\
\text { unfiltered, } \\
\text { CFU/100mL } \\
\text { (61213) }\end{array}$ \\
\hline \multicolumn{5}{|c|}{ Sand and gravel wells } \\
\hline HE 622 & $<2$ & $<1$ & $<1$ & $<1$ \\
\hline HE1929 & $<2$ & $<1$ & 998 & $<1$ \\
\hline OE1460 & $<2$ & $<1$ & 1 & $<1$ \\
\hline OE1468 & $<2$ & $<1$ & $<1$ & $<1$ \\
\hline SA1501 & $<2$ & $<1$ & $<1$ & $<1$ \\
\hline SA2259 & $<2$ & $<1$ & 90 & $<1$ \\
\hline SN1366 & $<2$ & $<1$ & 3 & $<1$ \\
\hline SO 605 & $<2$ & $<1$ & 2 & $<1$ \\
\hline SO 814 & $<2$ & $<1$ & 2 & $<1$ \\
\hline \multicolumn{5}{|c|}{ Bedrock wells } \\
\hline A667 & $<2$ & $<1$ & 4 & $<1$ \\
\hline FU1611 & $<2$ & $<1$ & 130 & $<1$ \\
\hline G 837 & $<2$ & $<1$ & $<1$ & $<1$ \\
\hline HE1459 & $<2$ & $<1$ & 50 & 54 \\
\hline HE1480 & $<2$ & $<1$ & 209 & $<1$ \\
\hline MT 406 & $<2$ & $<1$ & 2 & $<1$ \\
\hline OE2876 & $<2$ & $<1$ & 7 & 21 \\
\hline SA2806 & $<2$ & $<1$ & 8 & $<1$ \\
\hline SN1131 & $<2$ & $<1$ & 76 & 92 \\
\hline SO1037 & $<2$ & 1 & 12 & 67 \\
\hline SO1487 & $<2$ & $<1$ & 14 & $<1$ \\
\hline SO1658 & 2 & $<1$ & $<1$ & 1 \\
\hline
\end{tabular}

${ }^{1}$ A, Albany County; FU, Fulton County; G, Greene County; HE, Herkimer County; MT, Montgomery County; OE, Oneida County; SA, Saratoga County; SN, Schenectady County; SO, Schoharie County. 
Table 1-11. Physiochemical property values and concentrations of nutrients in groundwater samples collected in the Mohawk River Basin, New York, 2002, 2006, and 2011.

[(00080), U.S. Geological Survey National Water Information System parameter code; mg/L, milligrams per liter; $\mu \mathrm{S} / \mathrm{cm}$, microsiemens per centimeter at 25 degrees Celsius; N,

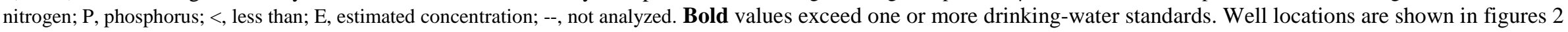
and 3]

\begin{tabular}{|c|c|c|c|c|c|c|c|c|c|c|c|c|c|}
\hline $\begin{array}{c}\text { Well } \\
\text { number }\end{array}$ & Year & Month & $\begin{array}{l}\text { Color, } \\
\text { platinum- } \\
\text { cobalt } \\
\text { units } \\
(00080)\end{array}$ & $\begin{array}{c}\text { Dissolved } \\
\text { oxygen, } \\
\text { mg/L } \\
(00300) \\
\end{array}$ & $\begin{array}{c}\mathrm{pH}, \\
\text { field, } \\
\text { standard } \\
\text { units } \\
(00400)\end{array}$ & $\begin{array}{c}\text { Specific } \\
\text { conductance, } \\
\text { field, } \\
\mu S / \mathrm{cm} \\
(00095)\end{array}$ & $\begin{array}{c}\text { Water } \\
\text { temperature, } \\
\text { field, } \\
\text { degrees } \\
\text { Celsius } \\
(00010) \\
\end{array}$ & $\begin{array}{l}\text { Ammonia } \\
\text { plus } \\
\text { organic-N, } \\
\text { filtered, } \\
\text { mg/L as N } \\
(00623) \\
\end{array}$ & $\begin{array}{l}\text { Ammonia, } \\
\text { filtered, } \\
\text { mg/L as N } \\
(00608)\end{array}$ & $\begin{array}{l}\text { Nitrate plus } \\
\text { nitrite, } \\
\text { filtered, } \\
\text { mg/L as N } \\
\text { (00631) }\end{array}$ & $\begin{array}{c}\text { Nitrite, } \\
\text { filtered, } \\
\text { mg/L as N } \\
(00613)\end{array}$ & $\begin{array}{l}\text { Ortho- } \\
\text { phosphate, } \\
\text { filtered, } \\
\text { mg/L as P } \\
\text { (00671) }\end{array}$ & $\begin{array}{c}\text { Organic } \\
\text { carbon, } \\
\text { unfiltered, } \\
\text { mg/L } \\
(00680)\end{array}$ \\
\hline \multicolumn{14}{|c|}{ Sand and gravel wells } \\
\hline \multirow{3}{*}{ HE 622} & 2002 & September & -- & 4.3 & 7.6 & 880 & 12.3 & $<0.10$ & $<0.04$ & 2.53 & $<0.008$ & $<0.02$ & E0.5 \\
\hline & 2006 & September & 2 & 7.9 & 7.2 & 1,040 & 9.9 & E0.08 & $<0.010$ & 2.60 & $<0.002$ & E0.004 & 1.0 \\
\hline & 2011 & July & $<1$ & 4.3 & 7.3 & 874 & 11.4 & 0.07 & $<0.010$ & 2.38 & $<0.001$ & 0.007 & 0.6 \\
\hline \multirow{3}{*}{ OE1460 } & 2002 & September & -- & 4.8 & 7.6 & 941 & 13.5 & $<0.10$ & $<0.04$ & 2.00 & $<0.008$ & $<0.02$ & 2.6 \\
\hline & 2006 & September & 2 & 5.6 & 7.1 & 910 & 13.6 & $<0.10$ & E0.006 & 2.04 & $<0.002$ & E0.004 & 1.1 \\
\hline & 2011 & July & $<1$ & 5.4 & 7.2 & 923 & 13.6 & $<0.05$ & $<0.010$ & 2.41 & $<0.001$ & 0.005 & 0.7 \\
\hline \multirow{3}{*}{ SA1501 } & 2002 & August & -- & -- & 7.3 & 507 & 12.8 & 0.42 & 0.32 & $<0.05$ & $<0.008$ & $<0.02$ & 2.6 \\
\hline & 2006 & September & 2 & 0.6 & 7.1 & 455 & 12.4 & 0.48 & 0.343 & E0.04 & $<0.002$ & 0.007 & 1.6 \\
\hline & 2011 & July & $<1$ & 3.9 & 7.3 & 353 & 11.7 & 0.25 & 0.164 & 0.04 & $<0.001$ & 0.011 & 2.2 \\
\hline \multicolumn{14}{|c|}{ Bedrock well } \\
\hline \multirow{3}{*}{ MT 406} & 2002 & September & -- & 0.1 & 4.8 & 1,080 & 9.4 & 0.52 & 0.43 & $<0.05$ & $<0.008$ & $<0.02$ & 0.8 \\
\hline & 2006 & August & 5 & 5.6 & 6.6 & 1,060 & 9.4 & 0.47 & 0.409 & $<0.06$ & $<0.002$ & 0.007 & $<1.0$ \\
\hline & 2011 & July & $<1$ & $<.3$ & 7.5 & 961 & 10.3 & 0.44 & 0.339 & $<0.02$ & $<0.001$ & 0.008 & 1.4 \\
\hline
\end{tabular}

${ }^{1}$ HE, Herkimer County; MT, Montgomery County; OE, Oneida County; SA, Saratoga County. 
Table 1-12. Concentrations of major ions in groundwater samples collected in the Mohawk River Basin, New York, 2002, 2006 , and 2011.

[(00900), U.S. Geological Survey National Water Information System parameter code; mg/L, milligrams per liter; $\mathrm{CaCO}_{3}$, calcium carbonate; <, less than; E, estimated concentration;

${ }^{\circ} \mathrm{C}$, degrees Celsius; lab, laboratory. Bold values exceed one or more drinking-water standards. Well locations are shown in figures 2 and 3 ]

\begin{tabular}{|c|c|c|c|c|c|c|c|c|c|c|c|c|c|c|}
\hline $\begin{array}{c}\text { Well } \\
\text { number }^{1}\end{array}$ & Year & $\begin{array}{l}\text { Hardness, } \\
\text { filtered, } \\
\mathrm{mg} / \mathrm{L} \text { as } \\
\mathrm{CaCO}_{3} \\
(00900)\end{array}$ & $\begin{array}{c}\text { Calcium, } \\
\text { filtered, } \\
\text { mg/L } \\
(00915)\end{array}$ & $\begin{array}{c}\text { Magnesium, } \\
\text { filtered, } \\
\text { mg/L } \\
(00925)\end{array}$ & $\begin{array}{l}\text { Potassium, } \\
\text { filtered, } \\
\text { mg/L } \\
(00935)\end{array}$ & $\begin{array}{c}\text { Sodium, } \\
\text { filtered, } \\
\text { mg/L } \\
(00930)\end{array}$ & $\begin{array}{c}\text { Acid } \\
\text { neutralizing } \\
\text { capacity, } \\
\text { unfiltered, } \\
\text { mg/L as } \\
\mathrm{CaCO}_{3} \\
(90410)\end{array}$ & $\begin{array}{l}\text { Alkalinity, } \\
\text { filtered, } \\
\text { fixed end } \\
\text { point, lab, } \\
\text { mg/L as } \\
\mathrm{CaCO}_{3} \\
(29801)\end{array}$ & $\begin{array}{c}\text { Bicarbonate }^{2} \text {, } \\
\text { filtered, } \\
\text { fixed end } \\
\text { point, lab, } \\
\text { mg/L } \\
(29805)\end{array}$ & $\begin{array}{c}\text { Chloride, } \\
\text { filtered, } \\
\text { mg/L } \\
(00940)\end{array}$ & $\begin{array}{c}\text { Fluoride, } \\
\text { filtered, } \\
\text { mg/L } \\
(00950)\end{array}$ & $\begin{array}{c}\text { Silica, } \\
\text { filtered, } \\
\mathrm{mg} / \mathrm{L} \\
(00955)\end{array}$ & $\begin{array}{c}\text { Sulfate, } \\
\text { filtered, } \\
\mathrm{mg} / \mathrm{L} \\
(00945)\end{array}$ & $\begin{array}{c}\text { Dissolved } \\
\text { solids, } \\
\text { dried at } \\
180^{\circ} \mathrm{C}, \\
\text { filtered, } \\
\mathrm{mg} / \mathrm{L} \\
(70300)\end{array}$ \\
\hline \multicolumn{15}{|c|}{ Sand and gravel wells } \\
\hline \multirow{3}{*}{ HE 622} & 2002 & 298 & 92.7 & 16.2 & 3.64 & 62.7 & 244 & 237 & 289 & 115 & E0.07 & 7.3 & 39.9 & 517 \\
\hline & 2006 & 314 & 97.8 & 17.0 & 3.60 & 68.2 & 242 & 243 & 296 & 130 & $<0.10$ & 7.22 & 35.3 & 531 \\
\hline & 2011 & 284 & 87.6 & 15.9 & 3.40 & 68.7 & 226 & 220 & 268 & 112 & 0.06 & 7.34 & 33.2 & 500 \\
\hline \multirow{3}{*}{ OE1460 } & 2002 & 366 & 95.1 & 31.2 & 2.10 & 60.0 & E288 & E233 & 284 & 105 & $<0.10$ & 6.0 & 48.4 & 545 \\
\hline & 2006 & 349 & 91.5 & 29.3 & 2.09 & 55.1 & 294 & 290 & 354 & 98.1 & E0.08 & 6.21 & 30.4 & 453 \\
\hline & 2011 & 357 & 98.0 & 27.4 & 1.92 & 56.6 & 247 & 251 & 306 & 101 & 0.05 & 6.11 & 18.0 & 507 \\
\hline \multirow{3}{*}{ SA1501 } & 2002 & 230 & 73.0 & 11.7 & 2.35 & 14.8 & 196 & 198 & 242 & 26.5 & 0.21 & 10.9 & 34.2 & 311 \\
\hline & 2006 & 227 & 72.6 & 11.2 & 2.38 & 15.2 & 210 & 212 & 259 & 21.9 & 0.21 & 11.8 & 19.5 & 283 \\
\hline & 2011 & 204 & 63.6 & 11.0 & 2.02 & 15.2 & 176 & 183 & 223 & 24.6 & 0.20 & 13.0 & 16.1 & 302 \\
\hline \multicolumn{15}{|c|}{ Bedrock well } \\
\hline \multirow{3}{*}{ MT 406} & 2002 & 502 & 148 & 32.4 & 4.40 & 41.3 & 290 & 289 & 353 & 108 & 0.33 & 7.7 & 151 & 708 \\
\hline & 2006 & 424 & 123 & 28.5 & 4.24 & 51.4 & 295 & 293 & 357 & 110 & 0.32 & 7.15 & 101 & 634 \\
\hline & 2011 & 385 & 113 & 25.0 & 4.10 & 53.3 & 294 & 194 & 237 & 89.0 & 0.32 & 7.38 & 79.8 & 577 \\
\hline
\end{tabular}

${ }^{1}$ HE, Herkimer County; MT, Montgomery County; OE, Oneida County; SA, Saratoga County.

${ }^{2}$ Bicarbonate concentrations calculated from laboratory alkalinity values. 
Table 1-13. Concentrations of trace elements and radionuclides in groundwater samples in the Mohawk River Basin, New York, 2002, 2006 , and 2011.

[(01105), U.S. Geological Survey National Water Information System parameter code; $\mu \mathrm{g} / \mathrm{L}$, micrograms per liter; pCi/L, picocuries per liter; <, less than; E, estimated concentration.

Bold values exceed one or more existing or proposed drinking-water standards. Well locations are shown in figures 2 and 3]

\begin{tabular}{|c|c|c|c|c|c|c|c|c|c|c|c|c|c|c|}
\hline $\begin{array}{c}\text { Well } \\
\text { number }{ }^{1}\end{array}$ & Year & $\begin{array}{c}\text { Aluminum, } \\
\text { unfiltered, } \\
\mu \mathrm{g} / \mathrm{L} \\
(01105)\end{array}$ & $\begin{array}{c}\text { Antimony, } \\
\text { unfiltered, } \\
\mu \mathrm{g} / \mathrm{L} \\
(01097)\end{array}$ & $\begin{array}{c}\text { Arsenic, } \\
\text { unfiltered, } \\
\mu \mathrm{g} / \mathrm{L} \\
(01002)\end{array}$ & $\begin{array}{c}\text { Barium, } \\
\text { unfiltered, } \\
\mu \mathrm{g} / \mathrm{L} \\
(01007)\end{array}$ & $\begin{array}{c}\text { Beryllium, } \\
\text { unfiltered, } \\
\mu \mathrm{g} / \mathrm{L} \\
(01012)\end{array}$ & $\begin{array}{c}\text { Boron, } \\
\text { filtered, } \\
\mu \mathrm{g} / \mathrm{L} \\
(01020)\end{array}$ & $\begin{array}{c}\text { Cadmium, } \\
\text { unfiltered, } \\
\mu \mathrm{g} / \mathrm{L} \\
(01027)\end{array}$ & $\begin{array}{c}\text { Chromium, } \\
\text { unfiltered, } \\
\mu \mathrm{g} / \mathrm{L} \\
(01034)\end{array}$ & $\begin{array}{c}\text { Cobalt, } \\
\text { unfiltered, } \\
\mu \mathrm{g} / \mathrm{L} \\
(01037)\end{array}$ & $\begin{array}{c}\text { Copper, } \\
\text { unfiltered, } \\
\mu \mathrm{g} / \mathrm{L} \\
(01042)\end{array}$ & $\begin{array}{c}\text { Iron, } \\
\text { filtered, } \\
\mu \mathrm{g} / \mathrm{L} \\
(01046) \\
\end{array}$ & $\begin{array}{c}\text { Iron, } \\
\text { unfiltered, } \\
\mu \mathrm{g} / \mathrm{L} \\
(01045)\end{array}$ & $\begin{array}{c}\text { Lead, } \\
\text { unfiltered, } \\
\mu \mathrm{g} / \mathrm{L} \\
(01051)\end{array}$ \\
\hline \multicolumn{15}{|c|}{ Sand and gravel wells } \\
\hline \multirow{3}{*}{ HE 622} & 2002 & $<2$ & $<0.9$ & E1 & 203 & $<0.06$ & 26 & $<0.04$ & $<0.8$ & $<1.00$ & 2.3 & $<10$ & 46 & $<1.00$ \\
\hline & 2006 & $<2$ & $<0.2$ & 0.60 & 200 & $<0.06$ & 27 & E0.03 & 0.23 & 0.183 & 3.6 & $<6$ & E6 & 0.15 \\
\hline & 2011 & $<3$ & $<0.2$ & 1.0 & 206 & $<0.02$ & 25 & $<0.05$ & 0.29 & 0.02 & 7.7 & $<3$ & $<5$ & 0.41 \\
\hline \multirow{3}{*}{ OE1460 } & 2002 & $<2$ & $<0.9$ & $<2$ & 94.7 & $<0.06$ & 31 & $<0.04$ & $<0.8$ & $<1.00$ & 3.5 & $<10$ & $<12$ & $<1.00$ \\
\hline & 2006 & $<2$ & $<0.2$ & 0.21 & 97.3 & $<0.06$ & 28 & $<0.04$ & 0.05 & 0.235 & 1.0 & $<6$ & E3 & E0.06 \\
\hline & 2011 & $<3$ & $<0.2$ & 0.37 & 85.7 & $<0.02$ & 19 & $<0.05$ & $<0.21$ & 0.05 & 9.6 & 4 & $<5$ & 0.16 \\
\hline \multirow{3}{*}{ SA1501 } & 2002 & $<2$ & $<0.9$ & $<2$ & 22.6 & $<0.06$ & 28 & 0.04 & $<0.8$ & $<1.00$ & 2.8 & $<10$ & E7 & $<1.00$ \\
\hline & 2006 & $<2$ & $<0.2$ & 0.38 & 19.8 & $<0.06$ & 24 & 0.05 & 0.45 & 0.742 & 1.2 & E4 & 7 & 0.07 \\
\hline & 2011 & $<3$ & $<0.2$ & 0.43 & 20.1 & $<0.02$ & 22 & $<0.05$ & 0.46 & 0.61 & 1.7 & 3 & $<5$ & 1.11 \\
\hline \multicolumn{15}{|c|}{ Bedrock well } \\
\hline \multirow{3}{*}{ MT 406} & 2002 & $<2$ & $<0.9$ & E1 & 114 & $<0.06$ & 178 & $<0.04$ & $<0.8$ & $<1.00$ & 1.6 & 169 & 236 & $<1.00$ \\
\hline & 2006 & $<2$ & $<0.2$ & 0.91 & 105 & $<0.06$ & 139 & $<0.04$ & 0.16 & 0.260 & 3.0 & 154 & 143 & $<0.06$ \\
\hline & 2011 & $<3$ & $<0.2$ & 0.80 & 126 & $<0.02$ & 121 & $<0.05$ & $<0.21$ & 0.03 & $<0.70$ & 102 & 132 & $<0.04$ \\
\hline
\end{tabular}


Table 1-13. Concentrations of trace elements and radionuclides in groundwater samples in the Mohawk River Basin, New York, 2002, 2006, and 2011Continued

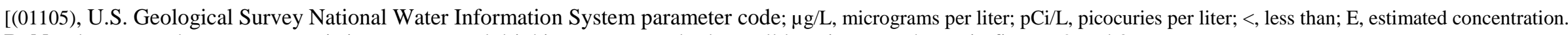
Bold values exceed one or more existing or proposed drinking-water standards. Well locations are shown in figures 2 and 3]

\begin{tabular}{|c|c|c|c|c|c|c|c|c|c|c|c|c|c|c|}
\hline $\begin{array}{c}\text { Well } \\
\text { number }^{1}\end{array}$ & Year & $\begin{array}{c}\text { Lithium, } \\
\text { unfiltered, } \\
\mu \mathrm{g} / \mathrm{L} \\
(01132)\end{array}$ & $\begin{array}{c}\text { Manganese, } \\
\text { filtered, } \\
\mu \mathrm{g} / \mathrm{L} \\
(01056)\end{array}$ & $\begin{array}{c}\text { Manganese, } \\
\text { unfiltered, } \\
\mu \mathrm{g} / \mathrm{L} \\
(01055)\end{array}$ & $\begin{array}{c}\text { Mercury, } \\
\text { unfiltered, } \\
\mu \mathrm{g} / \mathrm{L} \\
(71900)\end{array}$ & $\begin{array}{l}\text { Molybdenum, } \\
\text { unfiltered, } \\
\mu \mathrm{g} / \mathrm{L} \\
(01062)\end{array}$ & $\begin{array}{l}\text { Nickel, } \\
\text { unfiltered, } \\
\mu \mathrm{g} / \mathrm{L} \\
(01067)\end{array}$ & $\begin{array}{c}\text { Selenium, } \\
\text { unfiltered, } \\
\mu \mathrm{g} / \mathrm{L} \\
(01147)\end{array}$ & $\begin{array}{c}\text { Silver, } \\
\text { unfiltered, } \\
\mu \mathrm{g} / \mathrm{L} \\
(01077)\end{array}$ & $\begin{array}{c}\text { Strontium, } \\
\text { unfiltered, } \\
\mu \mathrm{g} / \mathrm{L} \\
(01082)\end{array}$ & $\begin{array}{c}\text { Thallium, } \\
\text { unfiltered, } \\
\mu \mathrm{g} / \mathrm{L} \\
(01059)\end{array}$ & $\begin{array}{c}\text { Zinc, } \\
\text { unfiltered, } \\
\mu \mathrm{g} / \mathrm{L} \\
(01092)\end{array}$ & $\begin{array}{l}\text { Radon-222, } \\
\text { unfiltered, } \\
\text { pCi/L } \\
(82303)\end{array}$ & $\begin{array}{c}\text { Uranium, } \\
\text { unfiltered, } \\
\mu \mathrm{g} / \mathrm{L} \\
(28011)\end{array}$ \\
\hline \multicolumn{15}{|c|}{ Sand and gravel wells } \\
\hline \multirow{3}{*}{ HE 622} & 2002 & 6.2 & $<2.0$ & $<2.4$ & $<0.011$ & $<0.2$ & 4.04 & 0.9 & $<0.05$ & 616 & $<0.90$ & 3 & 490 & 0.221 \\
\hline & 2006 & 5.7 & E0.5 & $<0.6$ & $<0.010$ & E0.1 & 1.96 & 0.71 & $<0.16$ & 651 & $<0.18$ & 9 & 450 & 0.221 \\
\hline & 2011 & 6.1 & 0.4 & 0.5 & $<0.005$ & 0.1 & 0.21 & 0.79 & $<0.01$ & 618 & $<0.06$ & $<2.4$ & 470 & 0.208 \\
\hline \multirow{3}{*}{ OE1460 } & 2002 & 9.7 & $<2.0$ & $<2.4$ & 0.030 & $<0.2$ & 4.04 & E0.2 & $<0.05$ & 407 & $<0.90$ & 4 & 590 & 0.149 \\
\hline & 2006 & 10.4 & $<0.6$ & $<0.6$ & $<0.010$ & $<0.2$ & 1.01 & E0.06 & $<0.16$ & 369 & $<0.18$ & E2 & 480 & 0.151 \\
\hline & 2011 & 7.6 & 0.4 & 0.5 & $<0.005$ & $<0.1$ & 0.44 & 0.09 & 0.07 & 229 & $<0.06$ & 8.5 & 560 & 0.137 \\
\hline \multirow{3}{*}{ SA1501 } & 2002 & 4.0 & 1,930 & 1,910 & $<0.011$ & 1.1 & 1.72 & $<0.4$ & $<0.05$ & 233 & $<0.90$ & 4 & 530 & 0.284 \\
\hline & 2006 & 4.7 & 1,960 & 2,020 & $<0.010$ & 1.0 & 2.29 & $<0.08$ & $<0.16$ & 237 & $<0.18$ & $<2$ & 500 & 0.236 \\
\hline & 2011 & 4.3 & 1,620 & 1,670 & $<0.005$ & 1.2 & 2.4 & 0.12 & $<0.01$ & 235 & $<0.06$ & $<2.4$ & 500 & 0.224 \\
\hline \multicolumn{15}{|c|}{ Bedrock well } \\
\hline \multirow{3}{*}{ MT 406} & 2002 & 18.4 & 27.6 & 27.6 & 0.020 & 2.4 & 6.35 & E0.2 & $<0.05$ & 2,420 & $<0.90$ & 2 & 170 & 1.95 \\
\hline & 2006 & 14.5 & 19.9 & 18.3 & $<0.010$ & 2.7 & 1.84 & $<0.08$ & $<0.16$ & 2,090 & $<0.18$ & 7 & 150 & 1.80 \\
\hline & 2011 & 10.9 & 17.1 & 19.1 & $<0.005$ & 2.8 & 0.50 & 0.08 & $<0.01$ & 1,810 & $<0.06$ & 10.7 & 106 & 1.48 \\
\hline
\end{tabular}

${ }^{1}$ HE, Herkimer County; MT, Montgomery County; OE, Oneida County; SA, Saratoga County. 
Table 1-14. Concentrations of pesticides and of volatile organic compounds detected in groundwater samples collected in the Mohawk River Basin, New York, 2002, 2006, and 2011.

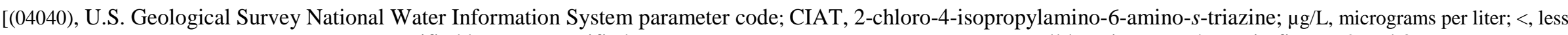
than; E, estimated concentration; M, presence verified but not quantified. Bold values indicate detected concentrations. Well locations are shown in figures 2 and 3$]$

\begin{tabular}{|c|c|c|c|c|c|c|c|c|c|c|c|c|c|}
\hline $\begin{array}{c}\text { Well } \\
\text { number }^{1}\end{array}$ & Year & $\begin{array}{c}\text { CIAT, } \\
\text { filtered, } \\
\mu \mathrm{g} / \mathrm{L} \\
(04040)\end{array}$ & $\begin{array}{c}\text { Atrazine, } \\
\text { filtered, } \\
\mu \mathrm{g} / \mathrm{L} \\
(39632) \\
\end{array}$ & $\begin{array}{c}\text { Metolachlor, } \\
\text { filtered, } \\
\mu \mathrm{g} / \mathrm{L} \\
(39415) \\
\end{array}$ & $\begin{array}{c}\text { Prometon, } \\
\text { filtered, } \\
\mu \mathrm{g} / \mathrm{L} \\
(04037) \\
\end{array}$ & $\begin{array}{c}\text { Simazine, } \\
\text { filtered, } \\
\mu \mathrm{g} / \mathrm{L} \\
(04035) \\
\end{array}$ & $\begin{array}{c}\text { Bromo- } \\
\text { dichloro- } \\
\text { methane, } \\
\text { unfiltered, } \\
\mu \mathrm{g} / \mathrm{L} \\
(32101)\end{array}$ & $\begin{array}{c}\text { Tribromo- } \\
\text { methane, } \\
\text { unfiltered, } \\
\mu \mathrm{g} / \mathrm{L} \\
(32104)\end{array}$ & $\begin{array}{c}\text { Dibromo- } \\
\text { chloro- } \\
\text { methane, } \\
\text { unfiltered, } \\
\mu \mathrm{g} / \mathrm{L} \\
(32105) \\
\end{array}$ & $\begin{array}{c}\text { Methyl tert- } \\
\text { butyl ether, } \\
\text { unfiltered, } \\
\mu \mathrm{g} / \mathrm{L} \\
(78032) \\
\end{array}$ & $\begin{array}{c}\text { Tetra- } \\
\text { chloro- } \\
\text { ethene, } \\
\text { unfiltered, } \\
\mu \mathrm{g} / \mathrm{L} \\
(34475) \\
\end{array}$ & $\begin{array}{c}\text { Toluene, } \\
\text { unfiltered, } \\
\mu \mathrm{g} / \mathrm{L} \\
(34010) \\
\end{array}$ & $\begin{array}{c}\text { Trichloro- } \\
\text { methane, } \\
\text { unfiltered, } \\
\mu \mathrm{g} / \mathrm{L} \\
(32106)\end{array}$ \\
\hline \multicolumn{14}{|c|}{ Sand and gravel wells } \\
\hline \multirow{3}{*}{ HE 622} & 2002 & $<0.006$ & $<0.007$ & $<0.013$ & $<0.01$ & $<0.005$ & $<0.1$ & $<0.2$ & $<0.2$ & 0.2 & $<0.1$ & $<0.1$ & $<0.1$ \\
\hline & 2006 & $<0.014$ & $<0.007$ & $<0.006$ & $<0.01$ & $<0.005$ & 0.3 & 0.8 & 0.7 & $<0.2$ & $<0.1$ & $<0.1$ & 0.2 \\
\hline & 2011 & E0.001 & $<0.008$ & $<0.020$ & $<0.01$ & $<0.006$ & $<0.1$ & $<0.2$ & $<0.2$ & $<0.2$ & $<0.1$ & $<0.1$ & $<0.1$ \\
\hline \multirow{3}{*}{ OE1460 } & 2002 & E0.040 & 0.022 & $<0.013$ & $<0.01$ & $<0.005$ & 0.2 & 0.3 & 0.3 & $<0.2$ & 0.3 & $<0.1$ & 0.8 \\
\hline & 2006 & E0.033 & 0.024 & E0.002 & $<0.01$ & $<0.005$ & 0.1 & 0.5 & 0.3 & $<0.2$ & 0.4 & 0.2 & 0.1 \\
\hline & 2011 & E0.034 & 0.027 & $<0.020$ & $\mathbf{M}$ & 0.002 & $<0.1$ & $<0.2$ & $<0.2$ & $<0.2$ & 0.2 & $<0.1$ & 0.1 \\
\hline \multirow{3}{*}{ SA1501 } & 2002 & $<0.006$ & $<0.007$ & $<0.013$ & $<0.01$ & $<0.005$ & $<0.1$ & $<0.2$ & $<0.2$ & E0.1 & $<0.1$ & $<0.1$ & $<0.1$ \\
\hline & 2006 & $<0.014$ & $<0.007$ & $<0.006$ & $<0.01$ & $<0.005$ & $<0.1$ & $<0.2$ & $<0.2$ & $<0.2$ & $<0.1$ & $<0.1$ & $<0.1$ \\
\hline & 2011 & $<0.006$ & $<0.008$ & $<0.020$ & $<0.01$ & $<0.006$ & $<0.1$ & $<0.2$ & $<0.2$ & $<0.2$ & $<0.1$ & $<0.1$ & $<0.1$ \\
\hline \multicolumn{14}{|c|}{ Bedrock well } \\
\hline \multirow{3}{*}{ MT 406} & 2002 & $<0.006$ & $<0.007$ & $<0.013$ & $<0.01$ & $<0.005$ & $<0.1$ & $<0.2$ & $<0.2$ & $<0.2$ & $<0.1$ & $<0.1$ & $<0.1$ \\
\hline & 2006 & $<0.014$ & $<0.007$ & $<0.006$ & $<0.01$ & $<0.005$ & $<0.1$ & $<0.2$ & $<0.2$ & $<0.2$ & $<0.1$ & $<0.1$ & $<0.1$ \\
\hline & 2011 & $<0.006$ & $<0.008$ & $<0.020$ & $<0.01$ & $<0.006$ & $<0.1$ & $<0.2$ & $<0.2$ & $<0.2$ & $<0.1$ & $<0.1$ & $<0.1$ \\
\hline
\end{tabular}

${ }^{1}$ HE, Herkimer County; MT, Montgomery County; OE, Oneida County; SA, Saratoga County. 
Table 1-15. Bacteria in groundwater samples collected in the Mohawk River Basin, New York, 2006 and 2011.

[(84385), U.S. Geological Survey National Water Information System parameter code; CFU, colony-forming unit; mL, milliliter; <, less than; U, not detected. Well locations are shown in figures 2 and 3 ]

\begin{tabular}{|c|c|c|c|c|c|}
\hline $\begin{array}{c}\text { Well } \\
\text { number }^{1}\end{array}$ & Year & $\begin{array}{l}\text { Escherichia coli, } \\
\text { unfiltered, } \\
\text { Presencel } \\
\text { Absence } \\
\text { (84385) }\end{array}$ & $\begin{array}{l}\text { Fecal coliform, } \\
\text { membrane filtration, } \\
\text { unfiltered, } \\
\text { CFU/100mL } \\
(61215)\end{array}$ & $\begin{array}{l}\text { Heterotrophic plate } \\
\text { count, } \\
\text { unfiltered, } \\
\text { CFU/mL } \\
(31692)\end{array}$ & $\begin{array}{l}\text { Total coliform, } \\
\text { membrane } \\
\text { filtration, } \\
\text { unfiltered, } \\
\text { CFU/100mL } \\
\text { (61213) }\end{array}$ \\
\hline \multicolumn{6}{|c|}{ Sand and gravel wells } \\
\hline \multirow{2}{*}{ HE622 } & 2006 & $\mathrm{U}$ & $<5$ & $<1$ & $<1$ \\
\hline & 2011 & $\mathrm{U}$ & $<1$ & $<1$ & $<1$ \\
\hline \multirow{2}{*}{ OE1460 } & 2006 & $\mathrm{U}$ & $<5$ & 13 & $<1$ \\
\hline & 2011 & $\mathrm{U}$ & $<1$ & 1 & $<1$ \\
\hline \multirow{2}{*}{ SA1501 } & 2006 & $\mathrm{U}$ & $<5$ & $<1$ & $<1$ \\
\hline & 2011 & $\mathrm{U}$ & $<1$ & $<1$ & $<1$ \\
\hline \multicolumn{6}{|c|}{ Bedrock well } \\
\hline \multirow{2}{*}{ MT 406} & 2006 & $\mathrm{U}$ & $<5$ & 2 & $<1$ \\
\hline & 2011 & $\mathrm{U}$ & $<1$ & 2 & $<1$ \\
\hline
\end{tabular}

${ }^{1}$ HE, Herkimer County; MT, Montgomery County; OE, Oneida County; SA, Saratoga County. 
For more information concerning this report, contact

\section{Director}

U.S. Geological Survey

New York Water Science Center

425 Jordan Road

Troy, NY 12180-8349

dc_ny@usgs.gov

or visit our Web site at:

http://hy.water.usgs.gov 